\title{
EARLY CELTICITY IN SLOVENIA AND AT RHAETIC MAGRÈ (SCHIO)
}

From the area around lakes Maggiore and Como in the west clear across the northern alpine crest of the Italian peninsula to the Balkans (albeit primarily in Slovenia) in the east we find the following varieties of early Continental Celtic: Golaseccan /Lepontic (with highly archaic features by virtue of dramatically early attestation, ca. 550-350 BC); Camunic (meagerly recorded, etymologically opaque, but, if anything, probably mainly Celtic) in Valcamonica north of Lago d'Iseo, also beginning about 550 BC; RhaetoCeltic (also but fragmentarily recorded, ca. 450-40 BC) from various sites such as Vadenà (Pfatten) south of Bolzano (Bozen) in the Fritzens Sanseno and Magrè Horizons; Carnian (northward from Udine, evidenced chiefly by onomastics, e.g. present-day Cadore < ${ }^{*}$ Catubrigum 'battle-mount') and East Celtic in southwestern Austria and the Balkans (again but fragmentarily retrievable from, for example, Magdalensberg and the onomastics retrievable from Roman necropoli such as that at Ig south of the Ljubljana marshes; see Hamp [1976, 1978]).

Although not generally recognized as such by Celticists, a carpenter's chance find in November of 1912 of what became known as the Magrè staghorn votives remains the single most dramatic heuristic event for mapping early Celticity in northeastern Italy; cf. Solinas (1992-1994), who omits Magrè from her otherwise exhaustive survey of Celtic materials.

The initial discovery of these Rhaetic votives was made below the Collina del Castello (acropolis) escarpment at Magrè, a town in the Leogra Valley near Schio in the Veneto, some twenty miles northwest of Vicenza. Previously, however, Vicenza and its environs had been portrayed archaeologically as Venetic, rather than Rhaetic; see Pellegrini and Prosdocimi (1967:1.380-381). The Magrè find thus proved surprising in every way, and it soon became known to two prominent local authorities, Giuseppe Pellegrini (1866-1918) and Alfonso Alfonsi (? - 1922). Pellegrini was a distinguished archaeologist and an accomplished art historian who had been active at Etruscan Pitigliano at the end of the $19^{\text {th }}$ century. This native of the Marche had, moreover, been a research assistant at the archaeological museums of Bologna, Florence, Naples and Ancona before obtaining a professorship and museum

\footnotetext{
1 While Whatmough's (1921:245) comment that Pellegrini “... died of fatigue during the war ...” may strike the casual reader as an authentic crumb of sophisticated insider information, this is actually but one in a series of infelicities in his Magrè report. During the summer and autumn of 1918, Giuseppe Pellegrini was, in fact, working in the museum at Este and supervising the excavation of a Bronze Age lake dwelling site at Palude di Feniletto near Padua. It was there that he contracted typhoid fever, from which he died on December $2^{\text {nd }}$, 1918. We are grateful to Bolzano's Lorenzo Dal Ri, who introduced the author to the region's archaeology in
} 
directorship at Padua in 1907; see Pellegrini (1914). ${ }^{1}$ At the time of the discovery, Alfonso Alfonsi was acting curator of the National Museum in Este (Museo Nazionale Atestino) and de facto successor of the pioneering archaeologist Alessandro Prosdocimi (1843-1911). Alfonsi had conducted numerous excavations throughout il Veneto. Pellegrini and Alfonsi quickly collaborated to conduct a more systematic investigation of the Magrè site. Eventually, a total of twenty-two staghorn votives with well-defined and professionally authenticated provenance histories made their way from Magrè to the National Museum in Este (Inv. Nos. 58808-58817, 58819 are still recorded), where they presumably remain yet today.

Conversely, however, in The Prae-Italic Dialects of Italy (PID) Whatmough (1933:33-48) presented the Magrè votives as if they were twenty-three items, numbered 221 through 243 , but items 222 and 230 are actually three fragments of the same horn: PID 222][230 RITANMELKa][TURIEPU (with $\mathrm{nm}$ as a probable scribal inversion of a difficilior $m n)=$ Ritamnel Katuriebu $\mathrm{Pfor} *$ Reitiamnel Catu-ritos / -retos $=\mathrm{N}$ (dedicatory Etruscoid Genitive II) $+\mathrm{N}$ (Rhaeticization of a Celtic nominative: Catu-ritos / -retos); cf. RITAMNE in PID 221 and see the research concordance in Table 1 and our discussion below.

The twenty-two Magrè votives conserved at Este were inscribed in a North Etruscan alphabet and were presumably dedicated, so the majority of scholars now believe, primarily to Reitia (probably a Veneticization of $\rho \eta \theta \varepsilon l \sigma \alpha$ [dialectal $\rho \varepsilon i \theta \varepsilon i \sigma \alpha]$ nominative singular feminine of the aorist passive participle of $\varepsilon \varepsilon i \rho \omega$ 'to say, to tell, typically through a divine intermediary', medio-passive 'to ask'; derivationally and functionally akin to Ilithyia = Juno Lucina, who, like Reitia, presided over the travails of women, from $\varepsilon \lambda \eta \lambda v \theta v i$ to $\varepsilon \rho \chi o \mu \alpha l$ 'to come'). For discussions of Reitia, the Venetic Artemis (Orthia) or Athena who was possibly represented in plastic art only on Venetic coins (cf. similarly the role of coins in the veneration of Juno Lucina), as the primary recipient of the Magrè votives and on Magrè as a possible sister foundation of the women's Baratella sanctuaryscriptorium at Venetic Este, see Kretschmer (1949), Mastrocinque (1987:97-128), Pascal (1964:113-114) and Whatmough (1922).

The first publication of the Magrè find was prepared by Giuseppe Pellegrini as a survey that appeared posthumously in 1918, a work that many authorities, such as Alberto Mancini (1973:365), still consider a remarkable piece of analysis. On March $31^{\text {st }}, 1922$, just two months after the death of Este's Alfonso Alfonsi and nearly a decade after the initial find, Joshua Whatmough (1897-1964), then barely twenty-five, read the Magrè inscriptions at Este; see Whatmough (1921, 1923, 1933:33-48). Whatmough autopsied the Magrè inscriptions at the request of his mentor, the University of Manchester's Robert Seymour Conway (1864-1933), with whom he

the autumn of 1998 , for kindly supplying biographical information on Pellegrini, an outstanding student of the justly celebrated Eduardo Brizio at Bologna. Incidentally, as the DAIs Horst Blanck kindly informs us, Alessandro Prosdocimi was director of the Este museum from 1887 until 1909, when he retired, whereupon administration of the museum was entrusted to Alfonso Alfonsi, but who was formally appointed director as late as 1921, just one year before his death. 
would collaborate in publishing the monumental three volume The Prae-Italic Dialects of Italy $(=P I D)$ eleven years later.

Since Whatmough's survey --- and unfortunately many of his readings have by now been deemed both imprecise and questionable, the Magrè votives have been addressed numerous times, most notably by Alberto Mancini (1975), Maria Grazia Tibiletti Bruno (1978), Stefan Schumacher (1992) and Alessandro Morandi (1999); see the concordance in Table 1. In our discussion below, the Magrè and other Rhaetic inscriptions are referenced by their PID numbers, where available, optionally followed by the corresponding siglum in Schumacher's (1992) CIRCE (= Corpus inscriptionum raeticarum completum et emendatum) and a reference to Morandi (1999) $=\mathrm{MOR}+$ number. Venetic inscriptions are referenced by the sigla (e.g. Es $1=$ Este 1) in Pellegrini and Prosdocimi (1967). The writer examined the Magrè votives at the Museo Nazionale in Este on October 19 ${ }^{\text {th }}, 1998 .^{2}$

Relative, much less absolute, chronologies for the Magrè staghorns remain elusive. As an initial working hypothesis, however, it seems only reasonable to assume a relatively broad time span for a collection of votives that probably represents but a fraction of the ex voto remains that presumably accumulated in favissae over some three or four centuries during the sanctuary's putative existence. Even from the scant, regrettably largely decontextualized, archaeological evidence that has come down to us, it appears likely that votives were still being inscribed at Magrè during the final decades (ca. 70-50 BC) prior to its destruction as a sanctuary-scriptorium, a result of the Roman conquest, and ensuing imposition of Roman construction on its surface.

In his contribution to Italia omnium terrarum alumna (1988:121), Raffaele Carlo De Marinis, the authoritative and widely published Milan archaeologist, dated the

2 The following conventions have been adopted here: so-called "Etruscan $t$ " with an angled bar at its head $=t$, St. Andrew's Cross $t=\mathrm{X}$, arrowhead tau $=\uparrow$, so-called "Magrè thorn" $=\mathrm{p}$, presumably the ultimate source of runic thorn. San is indicated by $\breve{s}$. Gk. $\varphi$ is retained for $p h i$, while so-called "red" chi is represented by $\chi$, rather than $\psi$ (psi) which, with regional variants with and without the handle (so-called "crowfoot chi", Lejeune's [1974] $g^{2}$ ), was the actual morphology of chi in Etruscan, Rhaetic, Messapic, Venetic, Golaseccan / Lepontic and at Castaneda (crowfoot chi in two attestations to date); see Markey and Mees (2004). In passing, we note that phi is lacking in Golaseccan / Lepontic and that both phi and chi are absent at Tortora, at Novilara, in Oscan, Umbrian, Faliscan, Sicel and South Picene. In our transliterations here, syllabic punctuation is indicated by periods. Where indicated by puncts (typically three or six) in the inscriptions themselves, such "word" division is here indicated by a colon. We have inserted spaces to indicate "word" divisions, and these divisions often result from "etymological" interpretation of a scriptio continua text, while forward slashes (/) indicate actual line breaks in the originals.

The smooth undersides - the horns were sawed in halves, of PID 221-233, 236-240, 242-243 bear graffiti that sometimes resemble Roman numerals (e.g. PID 227 V//, PID 238 I I X I, PID 239 X I); that is, X, D, $\mathrm{V}, \mathrm{I},, \mathbf{N}, \mathbf{W}, / / /$, but also crowfoot chi and decorative arrowhead zeta-like $x$ 's. In fact, of the twenty-two votives, only four (PID 220-230 = a composite, 234, 235 and 241) lack such graffiti; see Whatmough (1933: 33-48). These graffiti are similar and sometimes identical to those found at Padua, Monte Pore, on the Vadena stele, the votive alphabet pins from the Baratella sanctuary-scriptorium at Venetic Este, the Negau B helmet and the various Sanzeno-Casalini votives and castings; see fn. 7 .

Five of the horns have "partials": PID 226 (]EMAnIs[), PID 235 (]ŠU), PID 240 (]IXINATVIXA), PID 241 (AXT[) and PID 242 (ATV[). These inscriptional fragments have been omitted by Morandi (1999) and Tibiletti Bruno (1978), and, in so far as "readings" are possible at all, have so far never been provided with "explanations"; see Table 1. 
related Vadena stele inscription (PID $196=\mathrm{BZ}-10$ ) to the 5th century BC (ca. 450400?). He mistransliterates the stele's inscription, however, as pnake vitamu laze, apparently confusing Rhaetic arrowhead tau $[\mathrm{bp}, \mathrm{t}]$ with Camunic arrowhead zeta [s]. $\mathrm{He}$ offers no further interpretation, but then abruptly proceeds to assign the Magrè inscriptions, which he also neglects to interpret, to the same century (ca. 450-400?). Pauli (1885:17 [Nr. 36], 107), Markey (2000) and numerous others have repeatedly interpreted Vadena's pnake as a Rhaeticized (Etruscoid-syncopated) Celtic $\operatorname{Ben}(n) a c o s$, a reading with which Whatmough (1934:31) eventually agreed, although he abstained from interpretive translation at PID 196; see also Pellegrini's (1985:108109, fn. 50) abortive attempt.

For De Marinis (1988:121), the chronologically diagnostic benchmark for dating Magrè's votives is the ousting of closed alpha (= Latin A) by so-called "open alpha" (an A on which the central crossbar parallels, rather than horizontally joins, one of its sides, thereby forming a letter shape that approximates and can sometimes be confused with that of $F$-shaped digamma). For De Marinis, the benchmark rule is: closed alpha until the end of the 5th century, but open alpha thereafter; see our discussion below and Markey (2001a:99-102).

Conversely, in view of its two versions of closed alpha, the second putatively earlier than the other, Morandi (1999:78) dates Magrè PID $221=$ MA-1 to the IIIrd century (ca. 250-200?). He then (1999:78) proceeds to date Magrè PID $222=$ MA-2, the final portion of which both he and Giuseppe Pellegrini convincingly reconstruct as a Celtic Ka[TuRIEbu] (= Caturito for Caturitos), to the IIIrd century as well; see Schmidt (1957:259) on -rito. In view, however, of the Celticity of its onomastics and the fact that its closed alpha is matched by Negau B from about $55 \mathrm{BC}$, Morandi's $3^{\text {rd }}$ century date seems far too early. Morandi (1999:79) concludes his Magrè chronologies by dating PID $231=$ MA-11 to the 4th century (ca. 350-300?), though this is the only Magrè inscription with two contrasting alpha's, the first of which is closed, and the second of which is open.

Finally, in the $P I D$, for reasons that are rather imperiously evasive (undefined "epigraphical evidence"), Whatmough (1933:34) categorically assigned the Magrè votives to about the middle of the $3^{\text {rd }}$ century; that is, within Este IV as he knew it, a period now generally considered roughly contemporaneous with La Tène B2 through C1 (ca. 300-175 BC in Padania); see De Marinis (1986), Riemer (1998). Earlier, Giuseppe Pellegrini (1918:176) had dated the stratum in which the Magrè votives were found to the closing phase of the pre-Roman Venetic period; that is, sometime just prior to about $150-100 \mathrm{BC}$.

The fact is that, while contrasting alpha's such as those on PID $231=$ MA-11 afford little or no uncontroversial evidence for dating the Magrè inscriptions, they certainly do evidence the contemporaneous or near contemporaneous performance of different epigraphic disciplines at Magrè. In reality, introduction of open alpha in the various North Italian epichoric systems must have varied widely, certainly earlier in Lepontic than Rhaetic, prospects De Marinis (1988:121) fails to entertain. In fact, the demonstrably late (ca. $55 \mathrm{BC}$ or shortly before) Negau B inscription, epigraphically 
influenced as it clearly is by Magrè, and the late Venetic Isonzo inscriptions (Is 1 and Is 2, ca. 100-50 BC) all have closed alpha; see Markey (2001a:124, 130). Subsequently, De Marinis (1990-1991:216) suggested that the appearance of open alpha was contingent upon the disappearance of digamma, a contingency that seems indicated by the history of Golaseccan / Lepontic alphabetism with its closed alpha and digamma in inscriptions from the $6^{\text {th }}$ through the $5^{\text {th }}$ century vs. its open alpha and conspicuous absence of digamma in inscriptions from some two centuries later. Indeed, we find closed alpha beside upsilon but no digamma at Lepontic Banco (PID 273), Tesserete (PID 268/II) and Vergiate (PID 300), but this is presumably indicative of digamma's marginalization as a semivowel. Cf. Magrè's (PID 237 = MA 17) ASUA, possibly for *ASVA, but VALT- and not *UALT- in the same inscription, and on upsilon vs. a marginalized digamma at Prestino (ca. 480-450 BC), see Markey and Mees (2003). Nevertheless, as we (2001:99-101) have demonstrated elsewhere, the universality of De Marinis's contingency hypothesis is vitiated by, inter alia, Camunic which deftly avoided the prospect of pernicious homographic confusion between open alpha, digamma and possibly even epsilon, as seems to have been the case on the late $6^{\text {th }}$ century Providence Situla (RISD Museum, Providence, Rhode Island, Inv. No. 32.245); see our discussion below and fn. 6 .

In contradistinction to its two-pronged open alpha, Camunic introduced a fourpronged digamma that is unique among North Italian alphabets, whereupon Camunic continued both digamma and open alpha. Then, too, despite their virtual homography, open alpha and canonical digamma simply co-existed at, for example, Monte Pore and Serso and in the discipline that produced the remarkable Sanzeno-Casalini votives (SZ 1-15, ca. 420-380 BC). Open alpha and digamma also coexist on the late VIth century (ca. 525 BC) Providence Situla (MOR 27), reputedly from Certosa, but here a twopronged epsilon has been aligned with a two-pronged digamma. Interestingly enough, at Etruscan Balone (Rovigo) about $450 \mathrm{BC}$, we find closed alpha, while digamma has but one downward prong, though it cannot be confused with $L$-shaped lambda nor with $V$-shaped upsilon, while epsilon has three horizontal, rather than angled, prongs; see Marinetti (1994).

Within the allegedly talismanic alphabetic disciplinae of northern Italy (with evident echoes throughout the eastern Mediterranean), alpha and digamma must have been open to persistent reciprocal morphological influence. In this tradition's Phase Two abecedaria, they would have been equipollent initials ( $a-e \ldots$ [full, unabbreviated consonant and vowel alphabet] $/ v-z=/ \mathrm{v}-\mathrm{d} / \ldots$ [abbreviated consonant only alphabet of Reitia veneration at Este]); see below for further definition of Phase Two alphabets.

Identification of the language and ethnicity of the Magrè inscriptions long remained as controversial as determination of their chronologies and epigraphic elucidation. Whatmough repeatedly $(1923: 69-72,1933: 4,34)$ categorized their dialect as "Kelt(o)-Illyrian", a vacuously hypothetical branch of Indo-European that embraced an equally fictive and now generally discredited Illyrian. In comparison with Whatmough's categorization, we may cite Massimo Pallottino's (1963:77-78) rather evasive, prejudicial and hardly more informative assessment some forty years later, an 
evaluation embraced by the venerable Giovan Battista Pellegrini (1985:122), that the "Liguri e Reti" as "nuclei tribali" were "cuturalmente arretrati e privi di autentiche tradizioni storiche. La penetrazione etrusca da sud e le invasioni celtiche da nord debbono aver alterato profondamente i caratteri di queste genti ...."

Despite Whatmough's (1934) resistance to Thurneysen's (1932) stunning equation of Magrè pinake with Etruscan zinace 'made, made for' (as an artistic signature) and thereby the insight that Rhaetic was necessarily Etruscan (or genetically Etruscoid or at the very least heavily influenced by Etruscan) and Kretschmer's (1932) impression that Rhaetic was a mixture of Indo-European and Etruscan, we now consider Rhaetic typologically Etruscoid, although it sometimes incorporated Indo-European elements, preeminently so with respect to (Celtic) onomastic items; see the relevant discussion and bibliographical references in Markey (2001a:135, 137). Further to the detriment of Whatmough's position, more than fifty years earlier, despite initial reservations (1885:101, 109), Carl Eugen Pauli (1839-1901) had been essentially correct in his contention that Rhaetic was probably Etruscan.

Albeit clearly influenced by both Venetic and North Etruscan, the East Rhaetic alphabet that emerged at Magrè was a distinctly independent epichoric accomplishment. It descended from a so-called (Etruscoid) Phase Two aev-Alphabet, that is, from an ancestral North Etruscan alphabet in which the first three letters were $a e v$, not $a b g(a b c)$; see Pandolfini and Prosdocimi (1990:13). Such alphabets evolved after implementation of an Etruscan (Vulci?) reform that dictated elimination of beta, gamma $(c)$, delta, $s^{+}$, omicron and $s^{\prime}$. The precise date of this early reform is unknown, but a best guess estimate is about $600 \mathrm{BC}$, though certainly prior to a later reform (ca. $570-560 \mathrm{BC}$ ) that ushered in so-called "Phase Three Alphabets" signaled by introduction, typically in alphabet final position (after chi), of an hour glass figure (8) to express /f/. Datable Phase Two Alphabets are evidenced as follows in northern Italy: Spina (from ca. 580-480), San Martino in Gattara (ca. 400), San Polo d'Enza near Reggio Emilia (Golasecca III A 3, ca. 400-375) and at Roncoferraro near Mantua (ca. 390); see Pandolfini's convenient catalogue in Pandolfini and Prosdocimi (1990:1994). Note that both the San Martino in Gattara and San Polo d'Enza sites are in Celtic horizons; see Bermond Montanari (1969:218-224, 226-228), Colonna (1974:4-5, 1119) and de Marinis (1977:27b and Figure 3:1).

Here we should underscore the fact that the role of Etruscan Mantua as a center for the spread of Etruscoid alphabetism in northern Italy, particularly to Golaseccan / Lepontic horizons, but probably also to Rhaetic sectors as well, should not be underestimated. Contrary to earlier impressions, the Mantua area must have hosted imposing and long-standing Etruscan enclaves, points of convergence for Greek, Celtic, Venetic and, of course, Etruscan trade and exchange; see the comprehensive state-of-theart report and copious bibliographical documentation by De Marinis (1986), a survey now somewhat dated by continuing (at $\mathrm{Ca}^{\prime}$ dei Monti in 2002) work at Etrusco-Celtic Monte Bibele (at Monterenzio south of Bologna, ca. 400-200 BC) and by De Marinis's own ongoing excavations at the Etruscan settlement at Forcello di Bagnolo S. Vito (southeast of Mantua on the triangle between the Mincio and the Po).

In the absence, as demonstrated below, of an indigenous zeta $(=/ \mathrm{d} /)$ and in contrast 
to Atestinian $v-z=/ \mathrm{v}-\mathrm{d} /$ (the abbreviated consonant only alphabet of Reitia veneration at Este), the Magrè alphabet's initial consonants would have been $v-h$.

Like all North Etruscan systems and in contrast to the five vowel systems (with $o$ ) of Venetic and Golaseccan / Lepontic, Magrè had but four vowels: $a, e, i, u$. Vocalic length was left unindicated (not by $V+h$, gemination, macrons, or any other diacritic device), nor, in the same vein, was consonant gemination indicated. Magrè's upsilon assumed both inverted $(\Lambda)$ and non-inverted $\mathbf{V}$-shapes. With but one dramatic exception, discussed below, its epsilon was the cardinal angled three (never four!) pronged epsilon (E) found in virtually all North Italian systems. It had the conventional single-stroke vertical iota. As pointed out above, it had both open and closed alpha, though the latter shape was dominant. Explicit diagnostic arguments and evidential details need not detain us here, but it appears that, as was certainly the case in contemporaneous Etruscan, Rhaetic vowel systems, including that at Magrè, were asymmetrical with a non velar $[a]$ :

${ }_{a}^{i} \quad u$

and therefore /u/, but not /a/, could approach backward $c$; see Agostiniani (2000:495)

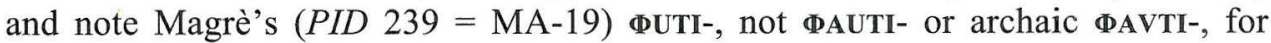
Celtic boudi- 'victory' as in British Boudicca (sic, Tacitus, Agr. 16.1). Accordingly, if etymologically equivalent, then one would expect Venetic volti- (Es 1,8$)$ to have been reflected at Magrè as *vulti-, rather than Magrè's (PID $237=$ MA 17) putatively equivalent valti-; see, however, our discussion below and recall the structuralists' graphemic / phonemic contingency ruling that, the fewer the vowel phonemes, the more room (phonological space) for non-distinctive variation on the part of each phoneme.

With respect to diphthongs, we emphasize at the outset that Magrè reflects NeoEtruscan ei $(e)<a i$ (attested since the beginning of the 5th century); see our discussion of Rhaeticizaton of theonymic Reitia below. As at other Rhaetic sites, we find $e i \sim i \sim$ $e$ oscillation; see Pellegrini and Prosdocimi (1967:2.146-147) for the comparable Venetic situation. Cf. reite (PID $227=\mathrm{MA}-8)$ and ritie $($ PID $224=\mathrm{MA}-5)$ and note eluku (WE-3, SZ-14, SZ-30) vs. fragmentarily preserved eiluke (possibly [RITI]EILUKE $=$ ritie iluke $<$ *reitiai ilukai) at Magrè (PID $223=$ MA-4) : Etr. ilucu '(destined) ritual offering' (Tegola di Capua) / eluce 'destined for'; see Rix (1985:23-24) and Zavaroni (1996:282-284, with an extensive research history) for discussions of Etr. ilucu, ilucve. As for rising diphthongs, we detect a general Etruscoid tendency toward their

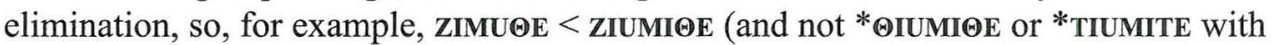
regular source to target devoicing) for $\Delta \imath \iota^{\prime} \dot{\eta} \delta \eta \varsigma$ on the Zinthrepus mirror from Talamone (ES V 121); see Van der Meer (1999), cf. Helbig (1880:260-264), ignored

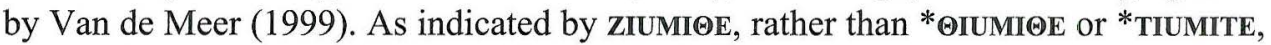
the initial palatal of rising diphthongs tended to be absorbed by the preceding

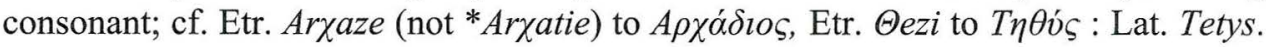


We note Magrè's RITIE (PID 224 = MA-5) and RIIIE (PID $229=$ MA-10) vs. REITE (PID 227 = MA-8); see our discussion of Magrè thorn ( $\mathbf{p}$ ) below. On the other hand, the vocalic nucleus was eliminated after the glide in Negau B's HARIXASTI, the Rhaeticization of a Germanic nom. sg. $i$-stem *Harjagastiz; see infra.

As for its consonants, Magrè presents surd shapes and only surd shapes.

For tau, Magrè used both the cross-barred, so-called "Etruscan $t$ " and the St. Andrew's Cross $t=\langle\mathrm{x}\rangle$, historically the $x$ extruded from crossed theta, an innovation apparently spawned at Chiusi that spread northward. Indeed, Central Etruscan ZILAO (with crossed theta) appears instead as ZILAX, that is, with St. Andrew's Cross tau, on the so-called "Second Rubiera Stele" (from about 640 BC), which was found as recently as 1984 in a riparian setting near Rubiera (Emilia); see De Simone (1992:10). ${ }^{3}$

Magrè obviously eschewed scrittura fonetica (cf. fn. 4) and utilized both $k$ and its aspirated counterpart $\chi(c h i)$ to the exclusion of $c$ and/or qoppa, but, as pointed out by Whatmough (1933:36) and numerous others, while Magrè attests $\varphi$, it lacked $p$; see our discussion below of ear-shaped vs. handled rho (not $p i)$. Magrè apparently merged $p$ and $\varphi$ as $\langle\Phi>$, which seems to have been a general tendency in Rhaetic systems. As evidence of this merger, compare, for example, upiku (Siebeneich / Settequerce, PID 191 = BZ-3, MOR 10; Castelgrifo PID $192=$ BZ-4, MOR 11) and upiku (Verona, PID 247 = VR-3, MOR 51) vs. uiiku (1x: Meclo, PID $210=$ NO-3, MOR 13) as a facilior rendering of upiku with "unmarked" iota for pi; see fn. 6.

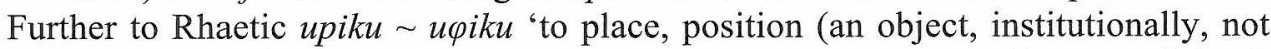
physically)?' with the locative or pertinentivo, compare fragmentarily attested South Picene upeke [- at Crecchio (CH 1), on which see Marinetti (1985:113-117), who was apparently oblivious of the possible Rhaetic analogue, and Untermann's (2000:801) laconic entry.

As a recap, then, while Magrè merged $p$ and $\varphi$ as $\varphi$, it retained both $k$ and $\chi$, albeit sometimes in free variation $(-k e \sim-\chi e)$, but did not merge them as $\chi$ in a symmetrical structural correlative to its merger of $p$ and $\varphi$ as $\varphi$.

Observers of early northern Italian epigraphy have long realized that, while letters $(\mathrm{P}, \mathrm{T}, \mathrm{K})$ that stood for plain stops in an Etruscan alfabeto princeps may represent fortis

3 Together with Adolfo Zavaroni, to whom many thanks for numereous kindnesses and instructive conversations are due, the author examined the Rubiera stelae at the Museo Civico di Reggio Emilia on September $14^{\text {th }}, 2002$. In contrast to Stele 2's nascent St. Andrew's Cross tau, Stele 1 has dotted theta throughout. As evidenced by Stele 2, which attests $k$ exclusively, it is clear that so-called "scrittura fonetica" ( $k$ before $a, c$ before $e / i$, and $q=$ qoppa before $u$ ) was no longer practised; so KUVEI, presumably the first member of a binomial onomastic formula. Both "cippi" present aev-alphabets as regional systems that persisted locally well into the 5th century; witness the AEVZ-shard from neighboring San Polo d'Enza, ca. 410-400 (Inv. No. S37/67, Museo di Reggio Emilia), a Celtic signature site; see Colonna (1974:4-5), de Marinis (1977:27b and Figure 3:1), Pandolfini and Prosdocimi (1990:73-74). Stele 1 attests handled $r$ ro (2x) exclusively, and ear-shaped $r h o$ was apparently a later introduction in North Etruscan alphabetism, so, for example, in KRALNIš from Villa Coviolo, division of San Rigo, ca. 440 (Inv. No. S96/1,Vetrina 96, Museo di Reggio Emilia) and exclusively so in the pitifully few epigraphic remnants retrieved from Marzabotto; see Colonna (loc. cit.). It seems likely that ear-shaped rho (along with crow-foot chi) was introduced to the Italian peninsula via the san-less "red" chi alphabetism of the Locrian colonies (chronologically: Epizephyrü, Hipponium, Nicotera and then, finally, Medma), probably about 540-490 BC; see Guarducci (1995:302-306), cf. Markey and Mees (2004:99-101). 
or lenis / voiceless or voiced stops indiscriminately in North Etruscan systems that portray Indo-European dialects, characters that represented aspirates $(\Phi, \Theta, \mathbf{X})$ in early Etruscan models were typically employed to disambiguate fortition / voice in such dialects, particularly Celtic and secondarily Germanic (Negau B). ${ }^{4}$ Thus it is that Negau B's HARIXASTI with "red" chi $(\psi)$, the Rhaeticization of a Germanic nom. sg. $i$ stem *Harjagastiz, is unambiguously Harigasti, not an ambiguous *Harigasti *Harikasti if spelled with kappa; see Markey (2001a:121-124). Alternatively, in Rhaetic systems that merged $p$ and $\varphi$ as $p, p$ was deployed to represent $/ \mathrm{b} /$ in IndoEuropean dialects; hence pnake $=$ Celtic Ben(n)acos at Vadena. Recall the absence of phi (merger with pi?), but retention of kappa vs. chi in Lepontic (Golaseccan).

Many investigators, among them Maria Grazia Tibilleti Bruno and the late Ernst Risch (1911-1988), who introduced the author to Rhaetic in July of 1972, considered Magrè's handled rho a pi. Seemingly, however, this identification is the result of some misguided attempt to align Magrè's handled $r h o$ with the closest matching letter shape in Venetic, namely Venetic's hooked shepherd's crook $p i$; cf. Tibilleti Bruno (1987:237) and Pellegrini (1985:109-110). In fact, a fully-fledged Roman $P$-shaped $p i$ is attested but once in Rhaetic, namely at Lothen (PU-1) in the cluster PD $=/ \mathrm{pr} /$, that

${ }^{4}$ The following vastly simplified tabular surveys of comparative consonantisms are presented here for ready reference; Indo-European, Greek, Latin, Osco-Umbrian, Venetic and Messapic vs. Etruscan. Nasals, resonants, laterals and spirants are basically the same among systems.

Part 1: Indo-European - Greek - Etruscan Correspondences

\begin{tabular}{|c|l|l|l|l|l|l|l|l|l|l|l|l|}
\hline IE & $b h$ & $d h$ & $g h$ & $g^{w} h$ & $g^{w}$ & $k^{w}$ & $b$ & $d$ & $g$ & $p$ & $t$ & $k$ \\
\hline Gk. & $\varphi$ & $\theta$ & $\chi$ & $\varphi \theta \chi$ & $\beta \delta \gamma$ & $\pi \tau \kappa$ & $\beta$ & $\delta$ & $\gamma$ & $\pi$ & $\tau$ & $\kappa$ \\
\hline Etr. & $\varphi$ & $\theta$ & $\chi$ & $\varphi \theta \chi$ & $p t k$ & $p t k$ & $p$ & $t$ & $k$ & $p$ & $t$ & $k$ \\
\hline
\end{tabular}

Part 2: Indo-European - (Selected) Italic - Messapic and Etruscan Correspondences

\begin{tabular}{|l|l|l|l|l|l|l|l|l|l|l|l|l|}
\hline IE & $b h$ & $d h$ & $g h$ & $g^{w} h$ & $g^{w}$ & $k^{w}$ & $b$ & $d$ & $g$ & $p$ & $t$ & $k$ \\
\hline Lat. & $f--b-$ & $f--b--d-$ & $h g f$ & $f--v-g u$ & $v g u$ & $q u$ & $b$ & $d$ & $g$ & $p$ & $t$ & $k$ \\
\hline Etr. & $f \sim p$ & $f \sim h-\theta$ & $h$ & $f$ & $v$ & $\chi$ & $p$ & $t$ & $k$ & $p$ & $t$ & $k$ \\
\hline Osc. & $f$ & $f$ & $h$ & $f$ & $b$ & $p$ & $b$ & $d$ & $g$ & $p$ & $t$ & $k$ \\
\hline Ven. & $f--b-$ & $f--d-$ & $h-$ & $?$ & $v$ & $k v$ & $b$ & $d$ & $g$ & $p$ & $t$ & $k$ \\
\hline Mess. & $b$ & $d$ & $g$ & $?$ & $?$ & $k$ & $b$ & $d$ & $g$ & $p$ & $t$ & $k$ \\
\hline
\end{tabular}

As pointed out by various investigators, numerous factors conspired to alter "predicted", conceivably lautgesetzlich outcomes: inverse spellings, different degrees of effort toward etymological transparency in nativizing loans (different nativization strategies), differences in loan input sources (Greek vs. Italic) and different

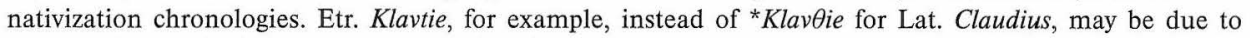

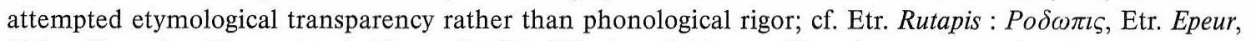

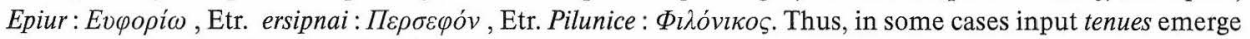
as tenues aspiratae in Etruscan $(p>)$, while in others the reverse is true $(>p)$. Moreover, in some cases, Etr. $t$ - has been assimilated to $\theta$-, and $h$ - to $f$ - and vice vers $a$ and $b>p$ to $f$; cf. Lat. Fausta vs. Etr. Fasti, Fausti, Hasti;

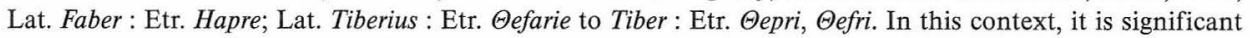
to ask why some anticipated configurations do not occur: given Pupluna and Fufluna, then why not ${ }^{*} H u p l u n a$ or *Hufluna? Attempts to nativize non-Indo-European loans also altered "predictable" outcomes, construed as regularities, particularly so in the case of Phoenician where the underlying vocalism remains largely unknown and the consonantism is known to have lacked equivalent graphemes in the target orthography: Etr. KarAazie 'Carthage' : QRTHDŠT 'new city', qutum 'pitcher' : KDM 'id.', španti 'basin' : ŞPN 'id.'. See, further, the commentary to Table 2. 
is, Roman $P$-shaped $p i$ plus triangular, ear-shaped, delta-like $r h o$. Although ear-shaped rho $(D)$ and handled ( $P$-shaped) rho certainly co-existed in numerous Greek and Etruscan (e.g. Cerveteri, Vulci) systems, as well as in some (e.g. Sicel) Italic systems, ear-shaped rho and only ear-shaped rho is found in Oscan, Umbrian, Venetic, Lepontic, Camunic, at Novilara, at Monte Pore, in Rhaetic at Sanzeno and in North Etruscan at Mantua, Spina, Adria, Marzabotto and Villa Coviolo (Reggio Emilia), while handled $r h o$ and/or $R$ (and only these shapes) are found in South Picene (only handled $r h o$, both angular and rounded), Faliscan (also $R$ ), Messapic (also $R$ ) and at Tortora (only handled rho, 7x); see Guarducci (1995:99). A Magrè type handled rho also occurs (1x) on the Castelrotto bone votive (VR-4) discussed below. Moreover, the Rhaetic inscription (PID $208=\mathrm{NO}-10)$ at Tavon near Sanzeno apparently also attests handled rho, probably IREKE, although this has been read by some as ILEKE, cf. Schumacher's (1992:152) ?]rileke:sa[?. Paradoxically, Tibilleti Bruno (1978:222) reads rho at Tavon, presumably because the "knob" of its handled rho is rounded rather than angular like the Magrè handled rho's, which, however, she seemingly prefers to read as pi's. Were she consistent, then she would surely have read Tavon as IPEKE with pi. Such speculation aside, the fact is that, at Magrè, ear-shaped rho and handled rho were presumably in free (allographic) variation, not only initially, but also medially and finally: e.g. \#ri- in PID 225 vs. \#Pi- in PID 221, 222, 228, 229), cf. \#Pivs. -uri- in PID 222, and note keP = [ker] in PID 229; see McLaughlin (1963:56-133) on the phonological significance of such graphemic orchestrations. Finally, we note that, with the exception of Camunic and its innovative paper-clip pi (a probable precursor of which is the North Etruscan humped or camelback pi on Stele 2 at Rubiera), presumably the progenitor of runic $\langle\mathrm{p}>, p i$ was one of the more immutable letter shapes of early northern Italian alphabetism. ${ }^{5}$

\footnotetext{
${ }^{5}$ Basic $p i$ shapes on the Italian peninsula fall into two major typological categories: (1) humped/semicircular, sometimes postulated as Proto-Italic (Sicel, Messapic, South Picene, Oscan), but presumably an outgrowth of (2), the shepherd's crook pi, a perpendicular stave with an oblique descender from its top, either to the left or the right (Etruscan, Umbrian, Golaseccan / Lepontic, Rhaetic at Sanzeno, and in the Novilara inscription). The shepherd's crook pi was sometimes hooked at the end, as in early Venetic, Messapic and at Tortora. Naturally, the unhooked shepherd's crook $p i$ was sometimes easily confused with lambda's that had their oblique descender attached to the head, rather than the foot, of the perpendicular stave; see Mancini (1975:303-305) for an enlightening discussion of this problem. In Rhaetic, and to some extent in Venetic as well, maintenance of a clear distinction between lambda, $p i$ and even asymmetrical upsilon's must have been problematic. This problem was solved in Camunic by introduction of the $M$-shaped so-called "paper-clip" pi, probably a fusion of a right-facing shepherd's crook $p i$ (or lambda) and a left-facing shepherd's crook pi (or lambda), a combination that may well have served as the model for runic $\langle p\rangle$; see Marstrander $(1928: 104)$. While alignment of the paper-clip /f/ of Tortora (vs. arrowhead tau as /f/ in Faliscan and hour glass 8, simplified as a colon in South Picene, as /f/ in Oscan, Umbrian and South Picene) with the paper-clip digamma of South Picene may be a productive line of inquiry for mapping the transmission of alphabetism on the Italian peninsula, alignment of paper-clip digamma with runic $\langle\mathrm{p}\rangle$ while omitting discussion of the Camunic paper-clip pi leads but to genetic confusion; pace the under-informed discussion in Letizia Lazzarini and Poccetti (2001:41-42), cf. Markey (2001a:95, 103). It was, of course, the humped/semicircular "Asiatic" pi that engendered "modern" Greek $p i$. It appears that one Rhaetic solution for maintaining a distinction between upsilon, lambda and $p i$ was a copout, namely selection of iota as an "unmarked" neutral substitution for lambda or pi, particularly between upsilons. This was presumably a serviceable solution given the redundancy of votive "texts". Note UIKU for UPIKU at Meclo (PID $210=$ NO-3, MOR 13), as pointed out above. Consider, moreover, Magrè's PID $227=$ MA-8 (right-reading scriptio continua) REIXEMUIU INA E = Reite muiu ina $e$ (with muiu ina e inverted, upsidedown) for *Reitie mulu zina e 'dedicated, offered to (and) made for Reitia', with passive verbs in asyndetic
} 
Magrè lacked the Sanzeno-Bolzano/Vadena and Negau (A [Ia]) arrowhead tau (or sampi) $=\uparrow$. Like Camunic, however, Magrè presents a saw-toothed thorn $(b)$ with either two or three teeth, probably historically a digraph, $t+s$. Indeed, in view of Magrè (PID 228 = MA-9) pinaxe : Etr. zinace [ $\mathrm{t}$ 'inake] 'made, elaboravit', one necessarily infers that Magrè $p$ represented $\left[\mathrm{t}^{\mathrm{S}}\right]$. However, Magrè also records xinaze (PID 231 = MA-11), with St. Andrew's Cross tau, which patterns with $\uparrow$ inaxe (SZ-1) at Sanzeno-Casalini, a site in proximity to Revo's $\uparrow$ erisna = Vače's $\uparrow$ erisna. We thus retrieve $\langle\mathrm{p}: \mathrm{x}: \uparrow: \uparrow>$ as an etymologically braided chain of divergent graphemes that could represent surficial [ $\mathrm{t}^{\mathrm{S}}$ ]; see Markey (2001a:142-143).

In contrast to Magrè (and Rhaetic alphabets generally), we recall that Prestino rendered $\left[\mathrm{t}^{\mathrm{S}}\right]$ with zeta: KozIs $=$ Celtic got $^{5}$ is $<\mathrm{IE} *$ ghosti-s $\left(\right.$ IEW 453). ${ }^{6}$ At Padua

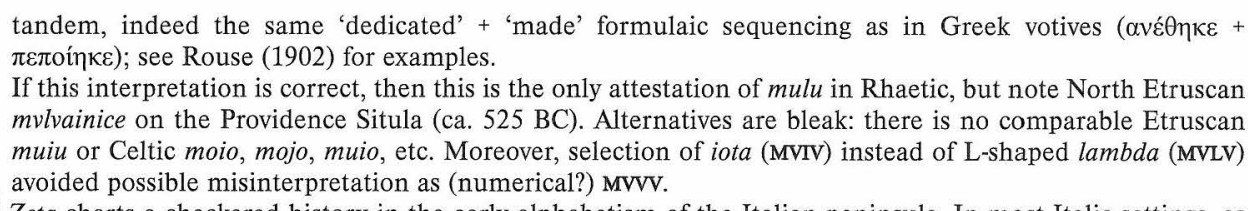

${ }^{6}$ Zeta charts a checkered history in the early alphabetism of the Italian peninsula. In most Italic settings, as noted below, it denoted [ts], its value in Etruscan, which is the source of, for example, Faliscan's I-shaped zeta (at Narce). In other epigraphic settings, however, zeta is absent, lacking at Italic Tortora and in the cryptic Novilara inscription.

While zeta makes single appearances at Prestino and Casate, it is otherwise absent in Lepontic. In the $2^{\text {nd }}$ $\mathrm{BC}$ century Casate inscription, we have: zv OšoRIS $=d v$ Ordorix ' $d v$ prince of maces', in which $d v$ plausibly represents a reversal of $v d$, the initials of a consonant only Phase Two abecedarium; see Schmidt (1957:252) on ordo- and Solinas (1995:341) on Casate. On deployment of san for dentals $(t / d)$ and clusters with dentals in the Celtic alphabetism of northern Italy, see Markey and Mees (2004).

In South Picene, which has ear-shaped delta, I-shaped zeta was apparently relegated to the tau slot to represent $/ t /$. The top and bottom crossbars of I-shaped Picene zeta for tau were retooled as globes (dots), yielding a dumbbell-shaped letter that represents /d/ in the Celtic Ic-inscription on Negau A: IUBNI gen. sg. of Dubnos; see Markey (2001a:105, 113-116). In Rhaetic, in addition to Magrè and Castelrotto (VR-4) as detailed below, we find zeta shapes only at Lothen, Steinberg and Sanzeno-Casalini (1x). On the Lothen (PU-1, MOR 7) belt buckle (later half of the 5th century) from St. Lorenzo di Sebato, Valle Pusteria (Pustertal), eELzURIE (with a zeta often misread as sigma) presumably corresponds to Etruscan VELoUR; that is, (early) Rhaetic $z$ : Etr. theta in an "inverse spelling"; for a classic restatement of the orthographic / phonological mechanics, see Hoenigswald (1960:9-10). In passing, we should point out that the buckle's deer motif is foreshadowed by comparable arrangements in the late VIIth century style of the "Maestro delle Spine di Pesce" at Cerveteri (cf., for example, Inv. No. 50364, Collezione Augusto Castellani, Villa Giulia) and in heavily Etruscan-influenced Faliscan venues (e.g. VIIth century Etrusco-geometric amphorae, particularly from Narce's necropolis of Contrada Morgi). Moreover, execution of the Lothen graphics finds a near match on the celebrated and contemporaneous Celtic terracotta from Matzhausen (Oberpfalz, Bavaria; Inv. No. IIc1244, Museum für Vor- und Frühgeschichte, Berlin). As Mitja Guštin has repeatedly informed us (p.c.), art forms that emerged in Etruria were quickly picked up in Celtic settings, either as imports or as skillful copies.

Cross of Lorraine shaped zeta's (T), conventionally transliterated as $t$ 's, have crossbars in immediate parallel proximity to each other across the middle of a central perpendicular stave. In Rhaetic, they are found only

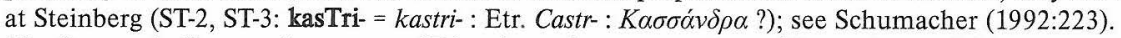

Finally, concluding our inventory of Rhaetic zeta's, we note that a "Camunic-style" (Castaneda, Montagna, Tresivio, Valcamonica - Cimbergo, Voltino) arrowhead zeta has so far been attested just once in a Rhaetic inscription, namely, as an isolated graffito on the "belly" of a votive from Sanzeno-Casalini (SZ-11, MOR 18; Inv. No. 7668, 'Castello del Buonconsiglio' [Monumenti e collezioni provenciali], Trent); see Pellegrini (1951:313, Fig. 11). In Camunic, however, arrowhead zeta represents /s/. On arrowhead zeta in Castaneda's demonstrably Celtic inscription; see Markey and Mees (2004). However, the Sanzeno-Casalini arrowhead zeta may well be a smith's mark, as it also occurs elsewhere at Sanzeno on castings; see Nothdurfter (1979:101, 103, Taf. 24-25) and de Marinis's (1986:107) enlightened and well documented commentary on this early practice for talismanic or apotropaic purposes and recall the graffiti on Negau B, Vadena and the undersides of the Magrè votives. 
(PID 244 = PA-1, MOR 52), however, we find Etsuale (a possible Celticity?) vs. Magrè's Estuale (PID 232 = MA-12), [E].stuva $(P I D 231=$ MA-11) and Es.stuatel $(P I D 233=$ MA-13). As a further possible, albeit remote, scribal Celticity in the Paduan inscription, note, if etymologically related, suspension of the nasal in Padua's utiku past passive participle 'brought' vs. utince 'led forth' in the Liber Linteus; see Facchetti (2002:11-12), who justifiably segments utince as ut-in- like alpn-in-, rep-in-. Suspension of nasals is, however, also periodically noted in Etruria, e.g. Atiuce $=$ Avtioxos : Lat. Antiochus.

Given the morphosyntactic comparability of Padua's kaian (ca. 500-480) and kaianin (with deictic, pronominal acc. -in 'this') on the Providence Situla (Certosa, ca. $525 \mathrm{BC}$ ), the Paduan ember palette would seem to share not only the same lexical, but also the same dialectal tradition. By the early fifth century, except in the dialects of the northwest, intervocalic $-y$ - had been lost (cf. Kae $<*$ Kaie : Lat. Caius), particularly between equal vowels: kaian $>* k a n$, whence Etrurian cana, can (- $l$ ) 'gift, image, stele' vs. $\chi a n u$ at Sanzeno-Casalini (SZ-1, ca. 420-380 BC) and Lothen (PU-1, ca. 450 BC). On the problematic semantic range and definitional complexity of cana; see the ample documentation and discussions by Agostiniani (1982:179, 189-190).

While I-shaped zeta rendered $\left[\mathrm{t}^{\mathrm{S}}\right]$ at Prestino (and in Oscan, Umbrian, Faliscan, Sicel and Messapic), it represented /d/ at Este, where Etruscoid I-shaped zeta assumed a Cross of Lorraine format with two slanted bars across the midpoint of its perpendicular stave. Significantly, Magrè attests this latter-day Este-shaped zeta just twice in a single inscription (PID $243=$ MA-23: USTIpu / ZEZEVE) that we now consider East Celtic rather than Rhaetic. In that inscription, detailed below, zeta represents $/ \mathrm{d} /:$ ZEZE- = dede 'gave, dedit'.

In addition to zeta as /d/ at Magrè, there is, in the entire Rhaetic sector, but one other probable occurrence of I-shaped zeta representing /d/; namely in VR-4 from Castelrotto (Comune di San Pietro di Cariano, Valpolicella, Verona). This epigraphically difficult left-reading inscription is in a Magrè-derived font on a pig bone (votive?). Castelrotto's M-shaped san, inverted upsilon $(\Lambda)$, handled rho $(\mathrm{P})$ and handled "red" chi $(\Psi)$ are all uniquely matched at Magrè. As is the case with PID 243 = MA-23, the Castelrotto inscription is presumably also Celtic. It possibly reads as follows: RUZINEš $\chi \mathbf{A N}=$ rudinešgan, in which at least RUZ is epigraphically unmistakable, probably rudi- for Celtic roudi- 'red'; cf. Schumacher (1992:207 and Tafel 2.3), see Schmidt 1957:262) and revisit fn. 5 below.

Although scribal practice and disciplinae scriptori at Magrè apparently recognized graphemic $\langle\mathrm{x}: \mathrm{p}: \mathrm{z}>$ as $/ \mathrm{t} /-/ \mathrm{t} \mathrm{s} /-/ \mathrm{d} /$ respectively, $\langle\mathrm{x}\rangle$ and $\langle\mathrm{p}\rangle$ were obviously the indigenous graphemes most actively utilized to represent dentals to the general exclusion of zeta. Nonetheless, we contend that, in addition to its recognition of Atestine use of zeta as /d/, Magrè alphabetism deployed its thorn in the same discretionary manner as theta was deployed in comparable North Italian Etruscoid systems, namely, as a "wild card" to render /d/ unambiguously in Indo-European, particularly Celtic, dialects. Just as discretionary theta was marked, so too was discretionary thorn. It was these marked, sometimes virtually moribund, graphemes that served as discretionary disambiguators in 
polyvalent systems in which, for example, St. Andrew's Cross tau could represent both $/ \mathrm{t} /$ and $/ \mathrm{d} /$. Consequently, arrowhead tau, a regional innovation, was deployed in the Vadena Stele inscription as a discretionary marked tau to represent /t/ unambiguously, while bivalent St. Andrew's Cross tau ( $t$ or $d$ ) was deployed to represent /d/: VIXAMU / $\mathbf{L A} \uparrow \mathbf{E}=$ Celtic windamolatos 'having most conspicuous warriors'. This is obviously an archaic (bipartite) superlative bahuvrīhi immediately comparable to Prestino's UVAMOKоZIS 'having supreme guests'. Vadena's final, after LA $\uparrow \mathbf{E}$, highly suspect sanlike figure is most credibly interpreted as a decorative graffito akin to the terminal decorative graffiti on Negau B and on the undersides of many of the Magrè votives; see Markey (2000) and fn. 2.

In line with these interpretations, we derive Magrè's usTipU (PID $243=\mathrm{MA}-23$ ) from an underlying Celtic anthroponym *Ostedō(n). Cf. Osti-names (Vi 2, Es 6, Es 133, Ts $1, \operatorname{Tr} 1, \operatorname{Tr} 3$ ) in Venetic settings at both Este and Làgole (Calalzo); see Morandi (1999:84), Pellegrini and Prosdocimi (1967:2.148-150), and RIG 4.4, 102, 103, 314. As a product of Thurneysen's Law (1946:Art. 75), Magrè's cognomalizing $-\mathrm{IbU}=-i d \bar{u}$ necessarily derives from $-e d \bar{u}<*-e d \bar{o}(n)$. We may therefore compare a PreCeltic *-edō(n), segmentable as *-ed-o( $(n)$, with the Oscan and Umbrian patronymic formans -idio- ( -edio-), a thematic composite of -id- + -yo-, Messapic patronymic $i d$-, and Greek -ida, which formed anthroponyms, gentilicia and patronyms, e.g. $\Pi \rho \imath \alpha \mu i \delta \eta \varsigma$; cf. the abbreviated account by Thurneysen (1946:58-59) and the uninformed discussion by Prosdocimi in Pandolfini and Prosdocimi (1990:292-295).

Having identified USTIpU (PID $243=\mathrm{MA}-23)$ as Ostid $\bar{u}<*$ Osted $\bar{u}$, we may now proceed to relate its composition to Magrè's KUNIIpU (PID $224=\mathrm{MA}-5)<*$ Cuniedū, Prestino's Plialegu (ca. 480-450 BC) = Plialed $\bar{u}$, Salassian (Lepontic) numismatic SEXE9U (ca. 400-377 BC) = Segedū, Verona's KoLITI.ETU or, better, KALLITI.ETU (PID

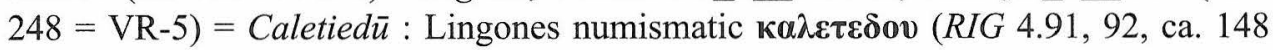
$\mathrm{BC})=$ Caleted $\bar{u}$, Ornavasso's OLETU $($ PID 307, corrected reading, ca. 190-75 BC) = Olledū, Cenomanian KELEśu (ca. 100-50 BC) = Celed $\bar{u}$ at Isola Rizza in Casalandri (Verona), built to *kel- 'to strike' (IEW 545-546); see Colbert de Beaulieu (1966), Solinas (1995:376, 1998:148), Schmidt (1957:160, 170, 186, 250-251, 265-266). On deployment of san for dentals $(t / d)$ and dental clusters in early Celtic alphabetism; see Markey and Mees (2004) and fn. 6.

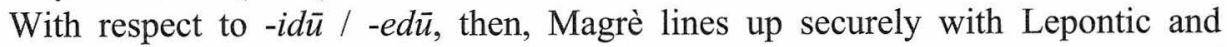
Gaulish (including Cenomanian) onomastic practice recorded both long before and long after the Celtic onslaught of $388 \mathrm{BC}$. Moreover, as Magrè's -idū evidences Thurneysen's Law and contrasts with -edū elsewhere in northern Italy, one might infer a comparatively late (ca. 70-50 BC?) date for PID 243 = MA-23; see our account further below. For now, however, compare Magrè's -idū $<-e d \bar{u}$ and Cembra's (PID 215 = CE-1) vino- $<*$ veno- in VINUTALINA $<*$ Venó-tal-ina $\bar{a}$, a situla inscription traditionally dated to between 390 and $350 \mathrm{BC}$ whose OSV-syntax and dedicatory intent are highly reminiscent of the celebrated second century BC Briona (Novara) inscription; see Solinas (1995:379-381) for a convenient survey of the latter. Cf., further, Cembra's vinUtalina $<*$ Veno-tal-inā, nom. sg. fem., as a hypocoristic 
diminutive, lit. 'the little one having the clan's brow, forehead, face,' and Briona's patronymic TANOTALIKNOI, nom. pl. masc. of a sg. *TANOTALIKNOS $=$ Dan (n)o-tal-ikno$s$ 'son of one having a judge's brow, forehead, face' : (Briona) TANOTALOS = Danno-tal$o$-s. We recall Latin Fronto, -ōnis, Celticized as Frontu, Frontunis, a calque on Celtic talo- 'forehead, brow, face' (OIr. taul <*talu-), along the peripheries of Romania, particularly in Romanized Noricum, but also in post-conquest (after ca. 15 BC) Valcamonica; see Falkner (1948), Markey (2001a:103), Schmidt (1957:91, 274, 289).?

Magrè's sigma consistently has but three strokes, as opposed to excessively multistroked serpentine sigma's in early Lepontic systems vs. three or four-stroked sigma's (consistently) in later Lepontic systems. Magrè apparently never evolved or adopted a butterfly or a Làgole $s a n$, and here one recalls that $s a n=/ \check{s} /$ designated palatal $s$, while sigma $=/ \mathrm{s} /$ designated apical $s$. Palatalization of $s$ before $/ \mathrm{i} /, / \mathrm{y} /$ or consonants was putatively a northern, rather than southern (Etrurian), phenomenon: so North Etruscan

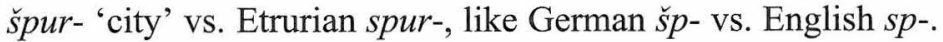

Magrè inscriptions attest $h$, indeed a 3-runged ladder $h$, but $/ \mathrm{h} /$ is generally absent in Rhaetic, and it is distributionally rare (regularly only word initially) in Etruscan. In fact, $h$ is a beacon for word boundaries in deciphering Etruscan scriptio continua. At Magrè, it is found in but two inscriptions: PID $221=$ MA-1 (HELANU) and PID $225=$ MA-6 (TRIAHI.S). Otherwise in Rhaetic, $h$ is found twice (also 3-runged) at Lothen (PU-1), twice (three-runged) in the Ca' dei Cavri inscription (PID $247=\mathrm{VR}-3)$ and, finally, possibly three times (SR-1, 2, 7) at Serso (Pergine, Trent) as follows: -VITAHUR (SR-1), -VITAHU.R (SR-7) and, possibly, as a two-runged variant in HETINU Or HETINA (SR-2). We approach the matter of $h$ 's representational status indirectly.

PID 229 = MA-10 (right reading, scriptio continua) RIPIEKERRINAKE = Ritie ker rinake for *Rietie $(i)$ ker tinaxe. Having emended the putatively erroneous scribal dittography of RR by substituting $r t$ and having etymologized tinake as tinaxe to fit the etymologically inferred semantactic requirements, this inscription seems transparent enough except for ker as an apparently problematic hapax. There is no comparable onomastic Ker in any probable donor language. We compare Ritie ker tinaxe '(it) was made as a ker for Reitia' and mi titasi cver menaxe (TLE 282, Bomarzo, a 3rd-2nd century mirror inscription) 'I was made as a kver for Tita'. We have seemingly comparable common denominator configurations and therefore equatable morphosyntactic constructions: (it) / I + N(dative / pertinentivo ) + cver $+\mathrm{V} \chi$ e; see Agostiniani (1982:106, 219-220). We therefore equate Magrè ker and Etr. cver, whatever its precise semantic value, but presumably 'gift, offering,' its long-standing traditional gloss supported in part by combinatory equation of cver turce and alpan turce. Moreover, in the majority of its occurrences, cver follows a theonym in the datival / pertinentivo case; see Zavaroni's (1996:324-325, fns. 97 \& 98) thorough research history. On ES 398, cver is personified as Cvera 'Grace, Benevolence'. Finally, we

\footnotetext{
${ }^{7}$ Segmentation of Cembra's VINUTALINA as VINU TALINA and interpretation of VINU as an abbreviated (why?) vinum and TALINA as an otherwise unattested Etruscoid gentilicium in -lina (cf. TAU RILINA on SZ-9 = MOR 20 at Sanzeno-Casalini, Etr. PUPLINA, etc.) is counterproductive, raising, rather than solving, a multitude of epigraphic, syntactic and etymological problems.
} 
note that gradual elimination of labial closure and regression of aspiration are clearly observable in Etruscan from the early 4th century onward: * $\chi v e s t n a->* \chi e s t n a->$

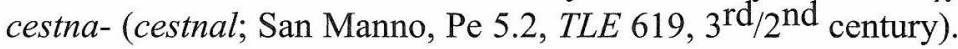

If construed as a datival recipient, then Ritie in PID $229=$ MA-10 presumably calques Ven. RE.I.TI(I)A.II (dat. sg. $\bar{a}$-stem). A Neo-Etruscoid (after ca. 375) Ritie could be legitimately derived from Venetic *Reitiai, albeit without remarking with $-i$. As argued by Agostiniani (2000:495), ${ }^{*}$ Riti-e- $i$ would derive from *Riti-ai $+-i$ to yield a late Neo-Etruscan feminine "absolute" singular in -ei. Etruscan "absolutes", we recall, functioned as morphologically undifferentiated nominatives or accusatives; see Facchetti (2002:fn. 38). In fact, such late 4th century Neo-Etruscan remarking is apparently recorded by Magrè's RITIEI (PID $224=$ MA-6). The argument here, then, is that Ven. dat. Reitiai was rephonologized (nativized) as a Rhaetic Ritie(i), a feminine "absolute", but that the thus nativized Ritie( $i)$ retained its original Venetic datival (pertinentivo) morpho-syntactic functions within Magrè's highly proscriptive votive setting. This argument seems validated by what may be presumed to be later replacement of Ritie( $i)$ as an early nativized approximation of Venetic datival grammaticality by a fully Rhaeticized Ritale in PID $228=$ MA-9 with the (later) datival (Pertinentivo II) desinence -ale common to both Rhaetic and Etruscan.

PID 228 = MA-9 (1 line: right-reading scriptio continua) reads as follows: RITALELEMAISPINAKE $=$ Ritale Lemais pinake $(\mathrm{N}$-ale $=$ Pertinentivo II (recipient) $+\mathrm{N}$ is = Ablativo I (agent) + Vke ' 'Made for Reitia by Lema', where Lema is perhaps akin to Ven. Lemetor-; see Pellegrini and Prosdocimi (1967:2.129-130). This interpretation avoids positing dittography (-le-le-) and then presuming Mais to be an (otherwise unknown) idionym.

Returning to PID $229=$ MA-10, we contend that, if Magrè ker = Etr. cver, then $k w$ $>k$ - in Rhaetic (or at least at Magrè). By extension, one could assume that, in a structurally parallel rephonemicization and / or regraphemicization strategy upon general loss of labialization, $h v->h$-. Recall that both $k$ - and $k^{\mathrm{W}}-(q u-)$ in Latin loans were represented by $\chi$ - in Etruria. In both Etruscan and Atestine Venetic orthography, however, graphemic $\mathbf{~} \mathbf{H} / \mathbf{H V}=/ \mathrm{f} /$, the digamma of which yielded Lat. $f .{ }^{8}$ Alternatively, Venetic at Làgole (Cadore) and Würmlach opted for $\mathbf{H}$, rather than $\mathbf{V H} / \mathbf{H V}$, to represent /f/: HA.R.TO $(\mathrm{Gt} 14)=$ Harto. In Etruria, $h-=$ Lat. $f$, e.g. Etr. Herme $=$ Lat. Firmus, Etr. Hapre = Lat. Faber and revisit fn. 4.

Reiterating and hopefully refining arguments presented in Markey (2001a:95), we accept the convention that archaic Etruscan $<_{\mathrm{v}} / \mathrm{u}>$ (digamma / upsilon) represented semivocalic $w$, but suggest that $w$ later emerged as a labiodental [v] upon acquisition of stridency. Phonologically, then, Proto-Etruscan ${ }^{*} w$ later emerged as $v$ as a result of

${ }^{8}$ Incidentally, the late Arthur Gordon (1975:52-57) presented the fullest research history to date on recognition of the digraphs VH / HV as /f/, first by Wilhelm Deecke (1831-1897) in print in 1888 (if not in conversation before) and again three years later by Carl Pauli (1839-1901), then 52; cf. Hamp (1981:152-153). Unfortunately, both Deecke and Pauli found confirmation in Wolfgang Helbig's (1839-1915) "Manios hoax" of 1887, a masterful collaborative forgery that took epigraphers and classicists nearly a century to discredit. The list of worthies, in addition to Deecke and Pauli - Holger Pedersen, Carl Darling Buck, Ernst Pulgram and numerous others, even yet today, "sucked in" by Helbig et Cie. is no less than stunning. 
articulatory simplification (bilabial being arguably more marked than labiodental), while $v$ subsequently gave rise to $f$ upon acquisition of tenseness; that is: ${ }^{*} w$ $($ digamma $)>v($ digamma $)>f(\mathbf{V H} / \mathbf{H V}$ and later 8). Just so, as Cortsen (1935:178) pointed out, while $p>p^{h}(\varphi)>f$ in Etruscan, $f$ never becomes $p$; cf. Breyer (1993:21).

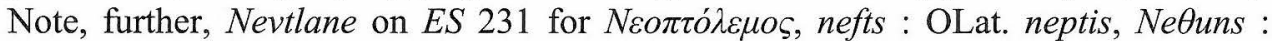
Neptunus with cluster simplification in Etruscan. We may therefore infer that, upon acquisition of stridency, an affricated Rhaetic $\varphi$ was variously (dialectally) identified with $/ \mathrm{v} /$ or $/ \mathrm{f} /$. This inference accounts for pEL- (pELzURIE-) at Lothen (PU-1) = Etruscan vel- (VELOUR) $<*$ wel-. Note, too, affrication of $\theta[\mathrm{t}]>z\left[\mathrm{t}^{\mathrm{S}}\right]$ in the nonetymological orthography of Lothen's pELZURIE- vs. Etr. VELOUR. Moreover, PRIMA (SZ-2) at Sanzeno-Casalini, presumably a nom sg. fem. idionym or epithet, the putatively syncopated counterpart of Sanzeno-Casalini's pIRIMA (SZ-1), is traditionally compared with Venetic Frema (VHREMA.I.-).

We conclude as follows. On the basis of etymological correlations, as selectively demonstrated below, we contend that, when confronted with possible representational ambiguities between digamma / upsilon and affricated $\varphi$, Rhaetic, specifically at Magrè, optionally deployed $\langle\mathrm{h}\rangle=/ \mathrm{f} /$ (reminiscent of Etr. $h$ - $=$ Lat. $f$-) to represent aspirated Celtic $w<\mathrm{v}\rangle=\left[\mathrm{w}^{\mathrm{h}}\right]$; on which see now De Bernardo Stempel (1990). In PID $221=$ MA1 , as detailed below, $h$ - in Helanu was presumably selected to represent Celtic Vellaunos (in which $v-=\left[\mathrm{w}^{\mathrm{h}}\right]$ ), thereby avoiding confusion with, for example, an Etruscoid Velna (in which $v_{-}=[\mathrm{w}]$ ). One is reminded of ulatucia $\sim$ flatucias at Larzac.

We may categorize Magrè's consonant inventory as follows where graphemic realizations are presented in angled brackets beside presumed phonetic values:

\begin{tabular}{|c|c|c|c|c|c|c|c|}
\hline \multicolumn{2}{|l|}{ Consonants } & Labials & Apicals & Gutturals & Sibilants & Laterals & Resonants \\
\hline \multirow{2}{*}{$\begin{array}{l}\text { Voiceless } \\
\text { Stops }\end{array}$} & $\begin{array}{l}\text { Full } \\
\text { expiration }\end{array}$ & $\begin{array}{l}\varphi<\varphi> \\
\uparrow(?)\end{array}$ & $\begin{array}{l}(\theta<\Theta>) \\
\downarrow\end{array}$ & $\begin{array}{l}\chi<\psi> \\
\downarrow \uparrow\end{array}$ & $\begin{array}{l}(t s<\mathrm{Z}>) \\
\downarrow\end{array}$ & & \\
\hline & $\begin{array}{l}\text { Restricted } \\
\text { expiration }\end{array}$ & $(p<\varphi>)$ & $t<\mathrm{X}>$ & $k<\mathrm{K}>$ & $\begin{array}{l}t s^{\prime}<\mathbf{p}> \\
\downarrow\end{array}$ & & \\
\hline \multicolumn{2}{|l|}{ Fricatives } & $f<\mathrm{H}>$ & $s<\mathbf{S}>$ & & $\breve{s}<\mathbf{M}>$ & & \\
\hline \multicolumn{2}{|l|}{ Nasals } & $m$ & $n$ & & & & \\
\hline \multicolumn{2}{|l|}{ Liquids } & $w\langle\mathrm{~F}\rangle \mid\langle\Lambda\rangle$ & & & & $l<\mathrm{L}>$ & $r<\mathrm{P}, \Delta\rangle$ \\
\hline
\end{tabular}

Table 2. The Rhaeto-Etruscoid Consonant System at Magrè

Commentary: There appears to have been a general tendency toward a regression of aspiration just as there was in Central Etruscan. However, only the $k$ vs. $\chi$ contrast is diagnostic, as $p$ is lacking and all instances of $\varphi$ are etymologically /b/ at Magrè. Nevertheless, a combination push and drag-chain movement in the direction of more restricted expiration is clear in the case of apicals and sibilants, whereby $\Theta$ and $z$ were eliminated in favor of $\mathbf{T}$ and $\mathbf{p}$ respectively. The same progression is seemingly evidenced by $\mathbf{b}\left[\right.$ ts' $\left.^{\prime}\right]>\mathbf{M}(\operatorname{san})[\check{s}]$; we have -ipu at Magrè vs. comparable -ešu at Isola Rizza, perhaps a window on linguistic competencies in a contact situation: $t s(\mathbb{Z})>t s$ ' (p) $>\check{s}$ (M). There was also an apparent tendency toward lenition whereby plosives were weakened to fricatives $(p>f)$ along a strength hierarchy. Lack of a voiced / voiceless contrast may have mattered less to speakers of Continental Celtic who may 
have been more concerned with contrasts in fortition than voice, than to speakers of other languages, such as Venetic, with a critical need for this contrast; see Watkins (1955), Evans (1967:403), Jackson (1953:545-548). Observe what are necessarily fortition distinctions between the two $<t>$ 's of Rheto-Celtic at Sanzeno / Vadenà: fortis arrowhead tau for Celtic/t/ vs. lenis St. Andrew's Cross tau (x) for Celtic /d/.

The paroxytonality of Celtic onomastic items embedded in Rhaetic inscriptions is reflected by accent-conditioned reduction (Etruscoid syncope) / assimilation; see De Bernardo Stempel (1994) and recall Celtic ben(n)ákos > pnáke at Vadena.

Celtic onomastic desinences were optionally subject to Rhaeticization, e.g. Celtic nom. sg. masc. -os could be Rhaeticized as $-e$, that is, as an Etruscan and Rhaetic absolute desinence (vs. Celtic and Italic voc. sg. -e), perhaps as part of a facultative interlingual discourse strategy, a quasi-pidginization process seeking common ground. Alternatively, it seems, Celtic -os could also be Rhaeticized as $-u$, rather than $-u s$, thereby avoiding confusion with Rhaetic's sigmatic genitive (Genitive I). The flexible rule-of-thumb for Rhaeticization of non-native onomastic desinences seems to have been as follows: forms with Italic (particularly Latin) analogues were Rhaeticized in the same manner as Italic (particularly Latin) forms were Etruscanized: e.g. Lat. -us (os) -ius (-ios) $>$ Etruscan and Rhaetic $-e$, -ie respectively. Forms without Italic analogues were, however, optionally grammaticalized / nativized (Celtic -os $>$ Rhaetic $-u$ ) as if Rhaetic (Etruscoid).

With the above survey in mind, we now proceed to comment further on Celticity in a selection of Magrè votives.

(1). PID 243 = MA-23: USTIpU / ZEZEVE $=$ Ostidū dedeve $<*$ Ostedō $(n)$ dedhē $(t)-$ we 'Ostido dedicated (me, this) emphatically'.

Cf. Gaulish $\delta \varepsilon \delta \varepsilon$ 'posuit, placed' (with the sense of $\alpha \nu \varepsilon \dot{\theta} \theta \eta \varepsilon \varepsilon$ ) $<* d e-d h \bar{e}-t$, and for the enclitic emphatic $-w e \sim-w \bar{e}(>-w \bar{i})$, hereby corroborated as the initial morpheme of the Castaneda inscription, see, further, Markey and Mees (2004). Cf. Latin vē-cors 'mad' = Old Welsh gui-cr 'brave', lit. '(too) much heart.' Bernard Mees (p.c.) points out that * $c o(m) w \bar{e}$ 'emphatically, utterly' underlies the coui of secoui at Chamalières in the figura etymologica of li. 7-8 (etic secoui toncnaman / toncsiiontio 'as well as they who may prosper that prosperity utterly') with etic reflecting formulaic utique and tonc- 'to prosper' : OIr. tocad 'luck, fortune, prosperity' < *tonketo- vs. e-grade OIr. técht(a)e 'proper' <*tenk-tyo-; pace Lambert (1997:156). For the mechanics, cf. OIr. co(a)ir 'proper, fitting' <*com-wari-; see Thurneysen (1946:503).

Magrè's syntagmatic dedeve is, presumably, a regional calque on formulaic

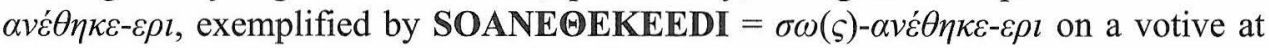
Adria (Cabinet 7, Museo archeologico di Adria, autopsied by the author on October $\left.25^{\text {th }}, 1998\right)$ 'in good cause (salvus) - dedicated - emphatically' with formulaic suffixation of the intensive prefix $\varepsilon \rho l$ - to the perennial Greek votive operator $\alpha v \varepsilon \dot{\theta} \theta \kappa \varepsilon$; pace Dubois (1995:177-178).

A photograph of PID 243 = MA-23 is displayed on Adolfo Zavaroni's admirable website, and the inscription has been accurately reproduced by Morandi (1999:Fig. 29,

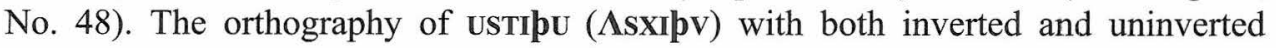


upsilons, St. Andrew's Cross tau and a thorn with three teeth is consistent with Magrè fonts. While the zeta's of ZEZEVE are generic Venetoid zeta's, the epsilon's are uniquely diagnostic. They find their closest match in the epsilon of the late Negau A (II) Celtic inscription KERUP $=\operatorname{Kerub}[$ ogios] 'he who harvests deer'; see Markey (2001a:116-118). This was probably the helmet's final inscription, plausibly engraved in Noricum, if not on the Magdalensberg, toward the middle of the first century BC; that is, just prior to its deposit at Ženjak (Negova / Negau).

(2). PID 237 = MA-17: (right-reading scriptio continua) KLEVIEVA.L.XIKINUASUA $=$ Klewie Valtikino ASUA $<*$ Klewios Waletikenos ASUA (ASVA) 'Clevios Valeticnos LIBENS MERITO'; that is, a binomial (Celtic or Venetoid) idionym + patronym configuration naming a (votive) dedicator followed by what we presume to be the abbreviation of an Etruscoid formula for dedicatory motivation, so DEDICATOR + (RECIPIENT) + DEDICATION MOTIVATION FORMULA. This presumed mixture of Celtic + a non-native votive formula, here Etruscoid, is echoed by Latin VSLM appended to the Gaulish votive from Sazeirat (Arrènes), on which see Lambert (1994:95).

Compare the inferred DEDICATION MOTIVATION-positioning of ASUA with the positioning of Etr. alpan turce 'gave the gift' in TLE 64 and the positioning of frequently abbreviated Latin motivation formulas such as $v$ (otum) s(olvit) l(ibens) $m$ (erito) or d(onum) d(edit) l(ibens); e.g. C. Aemilius / Felix / Aecur(nae) / v(otum) $s$ (olvit) l(ibens) $m$ (erito), CIL 3.3831 (Emona) = DEDICATOR + RECIPIENT + DEDICATION MOTIVATION FORMULA. Etr. alpan is, moreover, probably best glossed 'offering, gift' and not libens or libenter as traditionally proposed: alpan turce equates with donum dedit, not libens dedit. A plausible resolution of ASUA (= ASVA ?) might well be: $a($ lpan $) s(a c n i-) v(a c l)(a) r a$ 'perform(s) the sacred offering in praise (of X)'; see Facchetti (2002:34, 61-63).

The -ie outcome of *-ios in an underlying *Klewios (IEW 605-607) 'the renowned one' (uel sim.) is a Rheticization: cf. Etr. -ie for Lat. -ius (-ios) beside Gaul. -ios : OIr.-e $<*_{-} e(s)<*_{-y o s}$ vs. Ven., Osc. and South Picene -is (-es), Goth. -jis (after a short stem syllable as in harjis) and, finally, Lith. - $\hat{y} s /-i s$. Cf. unrelated Etr. cleva 'offering', conceivably as a collective in $-v a$ and thus possibly related to the $-v a$ - in the non-human (inanimate) plural marker - $(\chi / c) v a$-; see our discussion of estua- / estva- / etsua- below.

The patronym (or gentilicium) Valtikino has traditionally been paired with Ven. VOLTI $\chi$ ENEI (Es 1) = Voltigenei, VO.L.TI $\chi[\mathrm{N}]$ o.s. (Es 8) = Voltignos and similar Venetic names with Volti-; see the history of early research in Pellegrini and Prosdocimi (1967:2.205-206). Untermann (1961:1.17, 89-90, 92-93, 170) has devoted the fullest discussion to date to this matter, but then waffled in conclusion by asserting that, if the names are related at all, then it is only their initial components, volti- resp. valti-, either by remote genetic relationship or by borrowing from Venetic. He presumed (1961:1.92) that the suffixes -genei / -gnos and -kinu were but coincidental resemblances; cf. Lejeune (1974:42, 44, 47-48, 52-53), who derives Ven. volti- 'of desired (birth)' from IE *wl-ti- : Goth wulpus, but fails to address Magrè's Valtikinu. Finally, we note that, in his recent research history of the Valtikinu problem, Schumacher (1992:66) chides Untermann's conclusions, but then offers nothing 
memorable in return. For a dress rehearsal of Untermann (1961) with particular emphasis on the onomastic stock of the Rhaetic sector, mainly as reflected in postRomanization Latin, see Untermann (1959-1961).

As pointed out above, if Rhaetic had borrowed volt- from Venetic, then we would expect *vult-, not valt-, at Magrè; cf. Lat. Clovatius and Osc. Kluvatiis as examples of formations recorded in systems with and without omicron respectively. Conversely, if Venetic volt- were ultimately Etruscoid, then one might well expect the underlying form to have been *velt-; cf., for example, Etr. Velourna vs. pELzURIE (= Etr. *VelOurie) at Lothen : Lat. Volturnus; see fn. 7. Having identified Rhaetic as genetically Etruscoid, one would then expect *velt-, not valt, at Magrè; We thus infer that valt- is neither Etruscan nor Etruscoid and neither Venetic nor Italic, and, by a further process of elimination, having also discounted Illyrian, Ligurian, or some other nebulous non-Indo-European (Mediterranean) speech community as entirely specious possible sources, we necessarily infer that valt- is ultimately Celtic: valti-<valeti-, cf. OIr. failte 'gladness', Caesar's Valetiacus (BG.VII.32) : Lat. Laetus. If, however, Valtikino $=$ Valtikina (Etr. ${ }^{*}$ Valtici-na) were from Italic, then we clearly lack an underlying Italic *Valtikio-; cf. Etr. Melacina < Ital. *Melakio- as conjectured by Prosdocimi (1986:88-89). On the syncopation (valeti- $>$ valti-) assumed here, cf. Breton Verlamio <*Verolámion and see De Bernardo Stempel (1994).

We conclude that Valtikinu represents Rheticization of a Celtic *Valetikenos, a patronym in *ken- (-keno- -kno-) 'son of the prosperous, propitious one' (uel sim.); see Lejeune (1974:Art. 38), Schmidt (1957:100, 216-218) and note derivationally similar Celtic Enicenius (CIL 5.2620) from the Roman period at Este.

(3). PID 236 = MA-16: (right-reading) VAL.TE $\varphi$ NU = Valtebnu $<*$ Valetibenou 'of the two Valeti Women (suppliants)' $<$ Pre-Celtic ${ }^{*} w_{2}$ eleti-g ${ }^{w_{n}-o u}$ 'of the two joyous, pleasing, propitious women' (uel sim.) gen. dual : ${ }^{*} w_{2} H_{2}$ eleti-g ${ }^{w} e n-e H_{2}$ nom. sg. (IEW 473-474, 1111-1112); cf. Mandubenos and OIr. gen. dual ban $<{ }^{*} g w H_{2} n$-ou and see Thurneysen's (1946:Art. 287) prophetic hypothesis on a possible fem. gen. dual in -ou and Schmidt (1957:147-148) on names with benos / bena, which are never fronted as initial components. Cf. *Valetibena and Etr. Alpan : Lat. Laetitia, and consider possible reference to members of a college of sibyls.

This is a "possession inscription" comprised of the genitive of a syncopated compound feminine idionym with lowering of its composition vowel: $-i$ - $>-e$ - before $b$ as in Prestino's ARIUONEPOS $=$ Ariwonebos $<*$ Ariwonibhos, on which see Markey and Mees (2004). Syncopation of a gen. dual *-benou $\left(<*^{*} g^{w} H n-o u\right)>-b n u=-\varphi \mathrm{NU}$ is reminiscent of Vadena's * ben(n)ákos > PNAKE, but here we presumably have elimination of a weakly articulated vocoid before a nasal. Except for its lowered composition vowel, the first member of our compound here is identical with the Valti- in PID $237=$ MA-17.

(4). PID 239 = MA-19: (left-reading scriptio continua) LASXE $\varphi$ UXIXINU = Laste Boudigino for *Lastos Boudiginos; once again a binomial (Celtic, Venetoid) idionym + patronym configuration naming a (votive) dedicator. Boudiginos contains boudi(OIr. buaid, W budd) 'victory', as in British Boudicca, while -ginu corresponds to kinu in PID 237 = MA-17 (Valtikinu); see Schmidt (1957:100, 152, 154). Cf. 
pUXIIAKO.S. (Ca 17) = Boudiakos at Venetic Làgole within the context of a well documented Celticity; e.g. Làgole's $\varphi$ RIš (Ca 3) with butterfly (Lepontic) san for Briš= PRIś[--- (late VIIth /early VIth century Hallstatt vase fragment from Montmorot, Jura) for Brixios or Brixia: BRI (Es 103 bis); see the sketchy treatments in Pellegrini and Prosdocimi (1967:1.220, 463-464) and the insightful recovery report by Kaenel (2000:151,153) on this recent Jura find. Laste = Lat. Lastus (Lastuca, etc.).

With respect to Magrè Boudiginos vs. British Boudicca it is interesting to note that, similarly, the Celtic names attested in the Ig inscriptions (from the Roman necropolis south of the Ljubljana marshes) are more closely related to insular Celtic onomastics than to the Celtic names retrieved from neighboring Noricum or Pannonia; see Hamp (1976, 1978), Kos (1999:53 with copious references). From this, we concur with Kos (loc. cit.) that at least some of the Celts at both Magrè and Ig must have belonged to an early branch of immigrants, perhaps one related to the tribes of the Carni known to have settled in Venetic territory at an early date; see Šašel (1992:539). We recall that a Magrè - East Celtic (Slovene) connection is also reflected by the Celtic inscriptions on Negau (A) and the epigraphy of Negau (B).

(5). PID 221 = MA-1: (left-reading scriptio continua) RIXAMNEHELANU = Ritamne Helanu for *Reitiamne Vellaunos 'Vellaunos to Reitia (at the Reitialia)'.

As argued above, Ritamne is necessarily datival from *Reitiamnai; cf. RITAMN.U (WE-3) at Brixen and RITAME (PID $195=$ BZ-9) at Moritzing and see Laroche (1966:255-263) for a discussion and citation of the then current literature on Hitt. umna-, IE non-participial onomastic -mnos / -mna and Etr. -mne(i) / -mna as manifestations of "Mediterranean" onomasticization. In some Rhaetic dialects - $m n$ presumably became $-m(m)$ - (Moritzing) or $-n(n)$ - (Sanzeno-Casalini), much as $-m n->$ -mmn- > -nmn- in Venetic; cf. Lejeune (1971:420-412, n. 220; 1974:128-129, 138), Schumacher (1998:95-96).

This is possibly a local hypocoristic form of Ven. Reitia, but, more likely, an interlingual (Rhaetic / Celtic) abstraction for epiclesis. We note Celtic abstracts with $m n$ - such as OIr. flaithemna $<*$ vlati-mn-ad-tu-s 'lordship' and the epiclesis implied by Rhaetic theonyms: Magrè's ESIUM.NINUšU.R (PID 234 = MA-14) with Esiumni '(for) Esia', Steinberg's ESIMNESI (ST-3) $=$ Esi(a)mnesi $<*$ Esiamnai-si 'for or on behalf of Esia' and Sanzeno's ESIUNNE = Esiunne < *Esiamnai; see Morandi $(1999: 48,63-64,81)$. On Etruscoid alternation of $a$ and $u$, particularly before velar nasals; cf., for example,

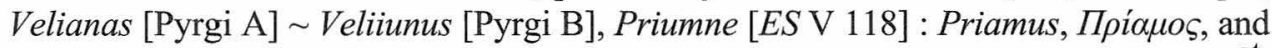
see Morandi (1991:119-120). Pace Helmut Rix's myopic insistence (p.c. Sept. $21^{\text {st }}$, 2001, at the Gubbio convegno) that the Sanzeno-Casalini votives fail to attest theonyms.

Our suggestion, then, is that Rhetic regularly suffixed -mne $(i)<-m n a-i$ to names of (ethnonymic) goddesses, pre-eminently Reitia at Magrè, but also Esia at Magrè, Steinberg and Sanzeno-Casalini, as deities venerated by state cults. With respect to this suggestion, cf. the analogous deployment of -āli- in Latin: Saturnus (theonym) vs. Saturnālia (veneration). Note, further, Central Etruscan VelOa (Veltune) : Lat. Voltumna :: VelOurna : Lat. Volturnālia; see Varro (L.L. 6.21, 7.45) on Volturnālia and Bader (1991) on -āli-, a provocative evaluation, whether one ultimately subscribes to her conclusions or not. 
We note, moreover, what appear to be reflexes of Esia- in Valtellina and Valcamonica: Montagna (Sondrio) PID 252 esiavau, Tresivio (Sondrio) PID 253 esiau (for Esio?) and Piancogno (Valcamonica) Rock 25 h 37 esi(u?)msz. On the other hand, Valcamonica presents items that appear comparable to estu- at Magrè and etsu- at Padua: Camunic (Berzo Demo 3 c) eztiau and the recently (2001) discovered Camunic espiau or estiau (Campanine di Cimbergo); see Tibiletti Bruno (1990:38-40, 92-93), Gavaldo and Solano (2001), Morandi $(1998: 109,124)$ and our discussion below of Magrè est-forms.

Interestingly enough, Esia is otherwise known only from the South. She was apparently an (archaic) Etruscan Ariadne / Persephone / Core and, as such, quite possibly the counterpart of an Italic (Oscan, Umbrian, Volscian, Marsian) Vesuna. ${ }^{9}$ An Etrurian Esia is, in fact, identified but twice, on two Praenestine mirrors that are reverses of each other; Brussels (Inv. No. R 1260 [818]) and Bologna (Inv. No. It. 746). For accounts of these important mirrors, see Colonna (1975:216), Lambrechts (1978: No. 10, pp. 67-73), Sassatelli (1981:No. 10, pp. 27-30, Figs. 10a-f) and Van der Meer (1995:51-54). ${ }^{10}$ Dating the mirrors is complicated, but is discussed by all four authors. On both mirrors, Esia is depicted as a shade brought by Artemis to Fufluns (functionally Bacchus / Dionysus / Liber) in the company of Minerva. The legends on the mirrors, inscribed by what are clearly different hands at widely different times, read as follows (letters within square brackets are missing; those in italics barely legible):

\footnotetext{
${ }^{9}$ The Esia-Vesuna constellation is the primary focus of an ongoing study being conducted together with Fausto Orioli, a portion of which was presented by the author on September $21^{\text {st }}, 2001$, at the Gubbio conference: "L'umbro e le altre lingue dell'Italia mediana antica", hosted by IRDAU (Istituto di recerche e documentazione sugli antichi umbri). Vesuna is apparently attested but once in an Etruscan context, namely on the so-called "Vesuna Mirror" (Walters Art Gallery, Baltimore, Maryland, Inv. No. WAG 54.85). The mirror portrays the goddess in an Ariadne-like setting, thereby permitting an equation: Ariadne (Etr. Area $\theta a$, Ara $a$ ) $=$ Esia = Vesuna; see the discussion and documentation by Zavaroni (1996:331-332). While our study discusses a possible Rhaetic Vesuna at Sanzeno-Casalini, it also presents evidence to show that the Vesuna Mirror, which mysteriously vanished to scholarship in 1884 only to resurface on a somewhat clandestine private art market some forty-two years later in 1926, is implicated as yet another Helbig hoax. The mirror's integrity as a probative integer of Vesuna veneration appears to have been compromised as part of a rather elaborate $19^{\text {th }}$ century gallery scam. Details are by now elusive, but the scam seems to have involved the avaricious Count Biagio Bucciosanti of Orvieto (d. 1889) as a rather reprobate property owner of the discovery site: one of eight Etruscan tombs said to have been located about three meters from the ancient Via Cassia at a place known locally as Fattoraccio ('the evil bailiff') in Comune di Castel Giorgio, sometime between October $14^{\text {th }}$ and $20^{\text {th }}, 1877$. The archaeologist who made the discovery was Riccardo Mancini (1843-1915), who emerges as a rather venal Helbig sycophant, while the overly ambitious Helbig probably orchestrated the scam. Alessandro Castellani (1824-1883) seems to have been the prospective fencer, possibly aided by the notorious Francesco "Checco" Martinetti (1833-1895) as the forger, and these two surely played major roles in the subsequent "Manios hoax" (fabricated sometime between 1880 and 1887); see the tantalizing hints of foul play in the confiscated (upon Helbig's dismissal) Mancini - Helbig dossier (Archiv Nr. M 571) at the Deutsches Archäologisches Institut (DAI) in Rome. Torquato Castellani, Alessandro's son, is known to have been active ca. 1877-1879 as an unusually skillful ceramic ware (maiolica) copyist in Orvieto; see Savage (1963:135).

10. We are grateful to Richard Daniel De Puma (p.c.) for these initial references. Dating the mirrors is difficult, but an Etruscan Esia-mythology was probably in place well before production of the Sanzeno-Casalini votives (ca. $420-380$ BC). Recently (September $5^{\text {th }}, 2001$ ), Roger Lambrechts kindly informed us (p.c.) as follows: "Le miroir Esia de Bologne est certainement le plus ancien. Sassatelli l'a daté du deuxième quart du Ve siècle. Il a certainement raison. Celui de Bruxelles est mieux conservé et plus beau. Dans Miroirs étrusques et prénestins des Musées Royaux, je l'ai daté de la seconde moitié du Ve siècle. C'est certainement
} 


$\begin{array}{lllll} & \text { Minerva } & \text { Fufluns } & \text { Artemis } & \text { Esia } \\ \text { Bologna (ca. 475-450 BC): menarva } & \text { fu[flu]nus } & \operatorname{artame}[\mathbf{s}] & \text { esia } \\ \text { Brussels (ca. 330-300 BC): } & \text { menarea } & \text { fuflunus } & \operatorname{artc[me]ns} & \text { esia }\end{array}$

At Magrè, then, we seem to glimpse a triad of Rhaetic lararian guardians of communal munificence and fertility: Estia - Esia (Ariadne / Vesuna) - Reitia (Artemis / Athena), perhaps in this order, cf. Pausanias 5.14.4. One recalls the mid-5 ${ }^{\text {th }}$ century (Eleusinian?) choral prayer in The Suppliant Maidens (li. 674-677): "And that other guardians be always renewed ( $\tau$ ' $k \tau \varepsilon \sigma \theta \alpha l$ ), we pray; and that Artemis-Hecate watch over the child-bed (גóxovs) of their women." (Loeb Library, Smyth translation). The

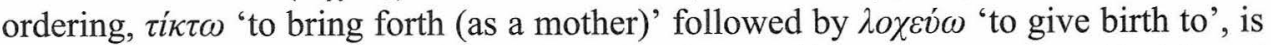
surely intentional, probably formulaic and quite possibly an expression of wish and fulfillment excerpted from a cult song.

(6). PID 234 = MA-14 (1 line: right-reading scriptio continua) ESIU.MININUŠU.R = Esiumni Inušur for *Esiumnei Inosur[ix] 'Inosurix for Esia (at the Esialia)' with *Esiumnei ultimately from *Esiamnai as discussed above. Pace Morandi’s (1999:81) reading Esiu.mni Nušur and contention that Nušur is an otherwise unknown idionym.

The final iota of the first term (Esiu.mni) is "re-used" as the initial iota of the second term (Inušu.r). Note the syllabic punctuation. The major epigraphic advantages of syllabic punctuation, made scrupulously regular to the point of becoming otiose in Venetic, are as follows. It aids "word / morph" identification in scriptio continua by: (1) revealing syllable boundaries and (2) blocking "the re-use option". The re-use option was exercised in scriptio continua whenever the final vowel or consonant of a foregoing word was "re-used" as the initial vowel or consonant of a following word. This practice was wide-spread, and it is also found in (early) Runic inscriptions. For example, the heroic Möjbro Stone (ca. 480-500 AD, Hagby Parish, just southwest of Uppsala in the heart of the ancient realm of the Svear), presents ISLAGINAR for IS\#SLAGINAR 'was slain'.

In the Inosurix retrieved here, we posit ino < eno; cf. Cembra's (PID $215=\mathrm{CE}-1)$ vino- $<*$ veno- in vinUtalina as discussed above. We thus have Inosurix from Enosurix 'the grand (good) king of the Inn'; see Schmidt (1957:91, 206, 226) on enoand note that the majority of eno- / ino-names are concentrated in neighboring Noricum.

Even from this rather cursory presentation we can firmly posit an East Celtic presence at Rhaetic Magrè and point to Celtic as an essential component of the diverse mixture that has enriched Slovenia's cultural heritage.

\footnotetext{
une erreur de ma part. Je me suis basé uniquement sur des critères stylistiques, qui effectivement nous reportent au Ve siècle. Mais j'aurais dû accorder plus d'attention à la typologie (prénestine) de l'objet, qui n'apparaît qu'à partir du dernier tiers du IVe siècle. Toutefois ce désaccord entre le style de la gravure et le type du miroir crée un gros problème. La seule explication (provisoire) de ce mystère semble être celle proposée par Sassatelli: un artiste du IVe s. aurait repris une composition plus vieille d'un siècle. Beaucoup d'auteurs élimi nent le problème en déclarant (toujours sans l'avoir vu!) que le miroir de Bruxelles est un faux. C'est une solution de facilité. J'ai eu ce miroir assez d'heures, et de jours, sous les yeux et dans les mains pour affirmer avec force qu'il est authentique. Je maintiens aujourd'hui encore cette position, même si l'explication de Sassatelli n'est pas entièrement convaincante."
} 


\section{References}

ADIEGO Lajara, Ignacio-Javier. 2001. Observaciones sobre el plural etrusco. Unpublished paper delivered at the $1^{\mathrm{O}}$ Convegno Internazionale sugli Antichi Umbri, L'umbro e le altre lingue dell Italia mediana antica. Gubbio, September $21^{\text {st }}, 2001$.

Agostiniani, Luciano. 1982. Le "iscrizioni parlanti" dell'Italia antica. (Lingue e iscrizioni dell'Italia antica, 3). Firenze: Leo S. Olschki Editore. 2000. La lingua. In: gli Etruschi, ed. Mario Torelli. Pp. 485-499. Milan: Bompiani.

ALFIERI, Nereo and Paolo Enrico Arias. 1958. Spina. Die neuentdeckte Etruskerstadt und die griechischen Vasen ihrer Gräber. Aufnahmen von Max Hirmer. Munich: Hirmer, 1958.

BADER, Françoise. 1991. Comparaison typologiques de l'etrusque et les langues indo-européennes: structures agglutinantes. Studi Etruschi 56.155-173.

BERMOND Montanari, Giovanna. 1969. La necropoli protostorica di S. Martino in Gattara (Ravenna). Studi Etruschi 37.213-228.

BREYER, Gertraud. 1993. Etruskisches Sprachgut in Lateinischen unter Ausschluß des spezifisch onomastischen Bereiches. (Orientalia Lovaniensia Analecta, 53). Louvain: Editions Peeters.

$C I E=$ Corpus inscriptionum Etruscarum . Carl Pauli et al./Academia litterarum regiae Borussica et Societatis litterarum regiae Saxonica/Istituto per l'archeologia etrusco-italica del Consiglio nazionale delle ricerche, eds. 1893-[1996]. Vol. 1-3. Leipzig: A. Barth/A. Meiner; and Rome: Istituto per l'archeologia etrusco-italica del Consiglio nazionale delle ricerche.

$C I L=$ Corpus inscriptionum Latinarum. Theodore Mommsen et al. / Academia litterarum regiae Borussica (and successor bodies), eds. 1863-. Vol. 1-17. Berlin: Georg Reimer/Walter de Gruyter \& Co.

COLBert DE BEAUlieu, Jean-Baptise. 1966. La monnaie de Caletedu et les zones du statère et du denier en Gaule. Revue archéologique du Centre 18.101-129.

Colbert DE BEAulieu, Jean-Baptiste and Brigitte Fischer. 1998. Recueil des inscriptions gauloises (R.I.G.). Volume IV: Les légendes monétaires. (XLV supplément à "Gallia"). Paris: CNRS Editions.

Colonna, Giovanni. 1974. Ricerche sugli Etruschi e sugli Umbri a nord degli Appennini. Studi Etruschi 42.3-24. 1975. Praeneste. 19. Studi Etruschi 43.216-218.

CORTSEN, Søren Peter. 1935. Literaturbericht 1928-1934: Etruskisch. Glotta 23.145-187.

De Bernardo Stempel, Patrizia. 1990. Einige Beobachtungen zu indogermanischem /w/ im Keltischen. In: Celtic Language, Celtic Culture: A Festschrift for Eric P. Hamp, ed. A. T. E. Matonis and Daniel F. Melia. Pp. 26-46. Van Nuys, CA: Ford \& Bailie, Publishers.

1994. Zum gallischen Akzent: eine sprachinterne Betrachtung. Zeitschrift für celtische Philologie 46.14-35.

DE MarINIs, Raffaele Carlo. 1977. The La Tène Culture of the Cisalpine Gauls. (Keltske studije) Posavski muzej Brežice 4.23-50.

1986. L'età gallica in Lombardia (IV-I secolo a. C.): Risultati delle ultime ricerche e problemi aperti. In: Atti. $2^{0}$ Convegno archaeologico regionale. La Lombardia tra protostoria e romanità. Como villa Olmo. 13.14.15. aprile 1984. (Società Archeologica Comense). Pp. 93-152. Como: New Press.

1988. Le popolazioni alpine di stirpe retica. In: Italia omnium terrarum alumna. La civiltà dei Veneti, Reti, Liguri, Celti, Piceni, Umbri, Latini, Campani e Iapigi, ed. G. Pugliese Carratelli. Pp. 99-155. Milano: Libri Scheiwiller. $2^{\text {nd }}$ ed. 1990.

1990-1991. Una nuova iscrizione lepontica su pietra da Mezzovico (Lugano). Aspetti epigrafici e inquadramento cronologico. Sibrium 21.201-218.

DE Simone, Carlo. 1992. Le iscrizione etrusche dei Cippi di Rubiera. (Archeologica Regiensia, 6). Reggio Emilia: Comune di Reggio Emilia, Assessorato alle istituzioni culturali, Civici musei.

DIL = Dictionary of the Irish Language. Dublin: Royal Irish Academy, 1983.

DuBoIS, Laurent. 1995. Inscriptions grecques dialectales de Grande Grèce. I. Colonies eubéennes. Colonies ioniennes. Emporia. (École pratique des hautes Études, IV ${ }^{\mathrm{e}}$ Section, Sciences Historiques et Philologiques, III. Hautes études du monde gréco-romain, 21). Geneva: Librairie Droz S.A.

ES = Etruskische Spiegel, see Körte, Körte, Gustav and (Johann) Adolf Klügmann. 1834-1897.

Evans, D. Ellis. 1967. Gaulish Personal Names. A Study of Some Continental Celtic Formations. Oxford: Clarendon Press.

FACCHETTI, Giulio M. 2002. Elementi di morfologia etrusca. Milano: Arcipelago Edizioni.

FALKNER, Margit. 1948. Die norischen Personennamen auf $-u$ und ihre kulturgeschichtliche Bedeutung. In: Frühgeschichte und Sprachwissenschaft. (Arbeiten aus dem Institut für allgemeine und vergleichende Sprachwissenschaft herausgegeben von W. Brandenstein, Graz, 1. Heft). Vienna: Gerold \& Co.

GAVALDO, Silvana and Serena Solano. 2001. Le nuove inscrizioni in caratteri nordetruschi in Valcamonica. Paper presented at: Etrusche nelle Alpi (Capodiponte, November 10-11, 2001). Capodiponte: Centro Camuno di Studi Preistorici. (In press). 
Gordon, Arthur E(rnest). 1975. The Inscribed Fibula Praenestina. Problems of Authenticity. (University of California Publications: Classical Studies, Vol. 16). Berkeley and Los Angeles: University of California Press.

GuARDUCCI, Margherita. 1995. Epigrafia greca. I. Caratteri e storia della disciplina. La scrittura greca dalle origini all 'età imperiale. Roma: Istituto poligrafico e zecca dello stato. $2^{\text {nd }}$ printing with corrections. $1^{\text {st }}$ ed. $=1967$.

Hamp, Eric P. 1976. On the Celtic Names of Ig. Acta Neophilologica 9.3-8.

1978. Further Remarks of the Celtic Names of Ig. Acta Neophilologica 11.57-63.

1981. Is the Fibula a Fake? American Journal of Philology 102.151-153.

1993. Venetic ke 'and'. Glotta 71.1-2.65.

1995. perëndi and perëndón. Linguistica Baltica (Kurylowicz Memorial Volume, Part Two) 4.277-278.

HelBIG, Wolfgang. 1880. Due specchi etruschi. Annali dell'instituto di corrispondenza archeologica (= Jahrbuch des Deutschen Archäologischen Instituts). 52.256-264. Roma: Coi tipi del Salviucci.

Hoenigswald, Henry M. 1960. Language Change and Linguistic Reconstruction. Chicago: The University of Chicago Press.

IEW = Pokorny, Julius. 1959. Indogermanisches etymologisches Wörterbuch. 1. Band. Bern-Munich: Francke Verlag.

JACKSON, Kenneth Hurlstone. 1953. Language and History in Early Britain. A Chronological Survey of the Brittonic Languages 1st to 12th c. A.D. Edinburgh: Edinburgh University Press.

KAENEL, Gilbert. 2000. Les relations transalpines à l'Age de Fer: territoire "lépontien" - Suisse occidentale - Jura. In: I Leponti tra mito e realtà. Raccolta di saggi in occasione della mostra, Locarno 20 maggio - 3 dicembre 2000, ed. Raffaele Carlo de Marinis and Simonetta Biaggio Simona. Vol. 2.151-158. Locarno: Gruppo Archeologico Ticino / Armando Dadò editore (distribuzione).

KöRTE, Gustav and (Johann) Adolf Klügmann. 1834-1897. Etruskische Spiegel. Founded by Eduard Gerhard. Vols. 1-5 (I-V). Berlin: Georg Reimer.

Kos, Marjeta Šašel. 1999. Pre-Roman Divinities of the Eastern Alps and Adriatic. (Situla, 38). Ljubljana: Narodni muzej Slovenije.

Kretschmer, Paul. 1932. Die Etruskerfrage und die Inschriften von Magrè. In: Symbolae philologicae O. A. Danielsson Octogenario dicatae, ed. Axel Nelson. Pp. 134-142. Uppsala (Upsaliae): A.-B. Lundequistska bokhandeln.

1949. Wem waren die raetischen Täfelchen von Magrè geweiht? Die Sprache (Zeitschrift für Sprachwissenschaft) 1.30-36.

LAMBERT, Pierre-Yves. 1994. La langue gauloise: description linguistique, commentaire d'inscriptions choisies. (Collection des Hesperides). Paris: Editions Errance. Rpt. 1997.

LAMBRECHTS, Roger. 1978. Les miroirs étrusques et prénestins des Musées Royaux d'Art et d'Histoire à Bruxelles. Brussels: Musées Royaux d'Art et d'Histoire.

LAROCHE, Emmanuel. 1966. Les noms des hittites. (Etudes linguistiques, IV). Paris: Librairie C. Klincksieck.

LeJeune, Michel. 1971. Lepontica. (Monographies linguistiques, 1). Paris: Société d'edition "les Belles Lettres" [= Documents gaulois et para-gaulois de Cisalpine. Etudes celtiques 12.2.337-500].

. 1974. Manuel de la langue vénète. (Indogermanische Bibliothek, I. Reihe: Lehr- und Handbücher). Heidelberg: Carl Winter Universitätsverlag.

Letizia LazZARINI, Maria and Paolo Poccetti. 2001. L'iscrizione paleoitalica da Tortora. (Il mondo enotrio tra VI e V secolo a.C., Atti dei seminari napoletani (1996-1998)). Napoli: Loffredo Editore.

Mancini, Alberto. 1973. Retico. Revista di epigrafia italica. Studi Etruschi 41.364-371.

1975. Iscrizioni retiche. Revista di epigrafia italica. Studi Etruschi 43.249-306.

MARINetTI, Anna. 1985. Le iscrizioni sudpicene. I. Testi. (Lingue e iscrizioni dell'Italia antica, 5). Firenze: Leo S. Olschki Editore.

1994. La documentazione epigrafica. In: Balone. Insediamento etrusco presso un ramo del Po. Rp. 8187. Rovigo: Comune di Rovigo.

MARKey, T. L. 2000 (1997). Rheto-Celtic PNAKE-VItAMUlate $={ }^{*}$ BEn(N)ACos windamolatos. General Linguistics 37.37-40.

2001a. A Tale of Two Helmets: The Negau A and B Inscriptions. The Journal of Indo-European Studies 29.69-172.

2001b. 'Ingvaeonic' *ster(i)r- 'star' and Astral Priests. NOWELE (North-Western European Language Evolution) 39.85-113.

Markey, T. L., and Bernard Mees. 2003. Prestino, Patrimony and the Plinys. Zeitschrift für celtische Philologie 53.116-167

2004. A Celtic Orphan from Castaneda. Zeitschrift für celtische Philologie 54.54-120. 
MarSTRANDER, Carl J. S. 1928. Om runene og runenavenes oprindelse. Norsk Tidsskrift for Sprogvidenskap 1.85188.

Mastrocinque, Attilio. 1987. Santuari e divinità dei Paleoveneti. Padova: La Linea Editrice.

McLaughlin, John C. 1963. A Graphemic-Phonemic Study of A Middle English Manuscript. The Hague: Mouton $\& \mathrm{Co}$.

MinsKY, Marvin. 1980. A Framework for Representing Knowledge. In: Frame Conceptions and Text Understanding. (Research in Text Theory / Untersuchung zur Texttheorie), ed. Dieter Metzing. Pp. Berlin New York: Walter de Gruyter.

Morandi, Alessandro. 1991. Nuovi lineamenti di lingua etrusca. Roma: Erre emme edizioni.

1998a. Epigrafia camuna. Osservazioni su alcuni aspetti della documentazione. Revue belge de philologie et d'histoire 76. 99-124.

1999. Il cippo di Castelciès nell'epigrafia retica. (Studia archaeologica, 103). Roma: "L’Erma" di Bretschneider.

NaGy, Gregory. 1974. Perkunas and Perunu. In: Antiquitates Indogermanica. Gedenkschrift fur Hermann Güntert zur 25. Wiederkehr seines Todestages am 23. April 1973, ed. Manfred Mayrhofer, Wolfgang Meid, Bernfried Schlerath, Rüdiger Schmitt. Pp. 113-131. Innsbruck: Innsbrucker Beiträge zur Spachwissenschaft. . 1990. Greek Mythology and Poetics. (Myth and Poetics). Ithaca and London: Cornell University Press.

PALlotTino, Massimo. 1963. Etruscologia. Milano: Editore Ulrico Hoepli. $5^{\text {th }}$ edition.

PANDOLFINI, Maristella and Aldo Luigi Prosdocimi. 1990. Alfabetari e insegnamento della scrittura in Etruria e nell 'Italia antica. (Istituto nazionale di studi etruschi ed italici, biblioteca di "Studi Etruschi," 20.). Firenze: Leo S. Olschki Editore.

PasCaL, Cecil Bennett. 1964. The Cults of Cisalpine Gaul. (Collection Latomus, Vol. LXXV). Brussels: Latomus, Revue d'études latines.

PaUlI, Carl Eugen. 1885. Die Inschriften nordetruskischen Alphabets. Mit sieben lithographischen Tafeln. (Altitalische Forschungen, 1. Bd.). Leipzig: Johann Ambrosius Barth.

Pellegrini, Giovan Battista. 1951. Osservazioni sulle nuove iscrizioni nordetrusche di Sanzeno. Archivio per l'Alto Adige 45.303-329.

1985. Reti e Retico. In: L'etrusco e le lingue dell'Italia antica. Atti del Convegno della Società Italiana di Glottologia. Pisa, 8 e 9 dicembre 1984, ed. Adriana Quattordio Moreschini. Pp. 95-128. Pisa: Giradini Editori e Stampatori. Rpt. as Chapter 7 (= Reti e Retico) in: Dal venetico al veneto. Studi linguistici preromani e romanzi. (Filologia veneta, Testi e studi 2). Pp. 101-132. Padova: Editoriale Programma, 1991.

Pellegrini, Giovan Battista, and Aldo Luigi Prosdocimi. 1967. La lingua venetica. 1. Le iscrizioni. 2. Studi. Padova: Istituto di glottologia dell'Università di Padova.

Pellegrini, Giuseppe, ed. 1914. Guida descrittiva del R. Museo Archeologico di Venezia. Sezione classica. Con speciale riguardo ai marmi scolpiti. I-II. Padova: Fratelli Drucker.

1918. Magrè (Vicenza). Tracce di un abitato e di un santuario, corna di cervo iscritte ed altre reliquie di una stipe votiva preromana, scoperta sul colle del Castello. Notizie degli Scavi di Antichità 16.169-207.

PID = The Prae-Italic Dialects of Italy. Conway, Robert Seymour, Joshua Whatmough and Sarah Elizabeth (Jackson) Johnson. 1933. The Prae Italic Dialects of Italy. Vols. 1-3. London: Milford, and Cambridge, MA: Harvard University Press. Rpt. Hildesheim: Olms, 1968. See Whatmough (1933). PID numbers in the text refer to inscriptions, not pages. The Rhaetic Corpus = Vol. II, Part III. Pp. 7-62, Nos. 188-253.

Prosdocimi, Aldo Luigi. 1986. I piú antichi documenti del celtico in Italia. In: Atti. $2^{0}$ Convegno archaeologico regionale. La Lombardia tra protostoria e romanità. Como villa Olmo. 13.14.15. aprile 1984. (Società Archeologica Comense). Pp. 67-92. Como: New Press.

REE $=$ Rivista di epigrafia etrusca, self-contained supplement of Studi etruschi.

RIEMER, Heiko. 1998. Eisenzeitliche Aschenaltäre aus dem Reitia-Heiltigtum von Este-Baratella / Italien. Ein Vorbericht. Archäologisches Korrespondenzblatt 28.3.423-430.

RIG (4) = Receueil des inscriptions gauloises, Vol. 4. See Colbert de Beaulieu and Fischer (1998).

RIX, Helmut. 1985. Descrizioni di rituali in etrusco e in italico. In: L'etrusco e le lingue dell'Italia antica. Atti del Convegno della Società Italiana di Glottologia. Pisa, 8 e 9 dicembre 1984, ed. Adriana Quattordio Moreschini. Pp. 21-37. Pisa: Giradini Editori e Stampatori.

RousE, William Henry Denham. 1902. Greek Votive Offerings. An Essay in the History of Greek Religion. Cambridge: Cambridge University Press. Rpt. Chicago: Ares Publishers, Inc. 1998.

ŠAšEL, Jaroslav. 1953. Emona. Rpt. in Opera Selecta. (Situla 30). Ljubljana: Narodni muzej, 1992. P. 559.

SASSATELl, Giuseppe. 1981. Corpus Speculorum Etruscorum: Italia 1. (Bologna, Museo Civico). Roma: "L'Erma" di Bretschneider. 
Savage, George. 1963. Forgeries, Fakes and Reproductions. A Handbook for the Collector. London: Barrie and Rockliff.

ScHMiDT, Karl Horst. 1957. Die Komposition in gallischen Personennamen. Zeitschrift für celtische Philologie 26.33-301. Also separately: Tübingen: Max Niemeyer, 1957.

SCHUMACHER, Stefan. 1992. Die rätischen Inschriften. Geschichte und heutiger Stand der Forschung. (Innsbrucker Beiträge zur Kulturwissenschaft. Sonderheft 79). Innsbruck: Verlag des Instituts für Sprachwissenschaft der Universität Innsbruck. . 1998. Sprachliche Gemeinsamkeiten zwischen Rätisch und Etruskisch. Der Schlern 72.2.90-114.

SOLINAS, Patrizia. 1992-1994. Sulla celticità linguistica nell'Italia antica: il leponzio. Da Biondelli e Mommsen ai nostri giorni. 1-2. Atti dell'Istituto veneto di scienze, lettere ed arti. Tomo CLI (1992-1993).1237-1335 and Tomo CLII (1993-1994).873-935.

. 1995 (1994). Il celtico in Italia. Revista di epigrafia italica. Sezione monografica. Studi Etruschi (Serie III). 60.311-408.

1998. Le iscrizioni in alfabeto leponzio dalla necropoli di Casalandri (Isola Rizza -VR-). In: La necropoli gallica di Casalandri a Isola Rizza (Verona), ed. Luciano Salzani. Pp. 143-148. Mantova: Società Archeologica Padana / Editrice S.A.P.

THURNEYSEN, Rudolf. 1933. Italisches. I. Die etruskischen Raeter. Glotta 21.1-7. . 1946. A Grammar of Old Irish. Dublin: The Dublin Institute for Advanced Studies. Rev. ed. 1966

TibilETti Bruno, Maria Grazia. 1978. Camuno, retico e pararetico. In: Lingue e dialetti dell'Italia antica. (Popoli e civiltà dell'Italia antica, VI), ed. Aldo Luigi Prosdocimi. Pp. 211-255. Roma: Biblioteca di storia patria.

. 1990. Nuove iscrizioni camune. Quaderni Camuni 49-50.29-171.

$\overline{\mathrm{TLE}}=$ Testimonia linguae Etruscae. Selegit recognovit et indice verborum instruxit Maximus Pallottino. (Biblioteca di studi superiori. Storia antica ed epigrafia, 24). 1954. Firenze: «La Nuova Italia» Editrice.

UNTERMANN, Jürgen. 1959-1961. Namenlandschaften im alten Oberitalien. Beiträge zur Namenforschung 10.1.74108 (1959), 10.2.121-159 (1959), 11.3.273-318 (1960), 12.1.1-30 (1961).

. 1961. Die venetischen Personennamen. 1-2. Wiesbaden: Otto Harrassowitz.

2000. Wörterbuch des Oskisch-Umbrischen. (Handbuch der italischen Dialekte. Begründet von Emil Vetter.

III. Band). Heidelberg: Carl Winter Universitätsverlag.

VAN DER MEER, L(ammert) Bouke. 1995. Interpretatio etrusca. Greek Myths on Etruscan Mirrors. Amsterdam: J. C. Gieben.

. 1999. Erus, Zinthrepus and Zimuthe: A Greek Myth in Etruscan Dress. In: Proceedings of the XVth International Congress of Classical Archaeology, Amsterdam, July 12-17, 1998. Classical Archaeology Towards the Third Millennium: Reflections and Perspectives (Allard Pierson Series, 12), ed. Roald F. Docter and Eric M. Moormann. Pp. 430-432. Amsterdam: Allard Pierson Museum.

VITALI, Daniele. 1998. I Celti e Spina. In: Spina e il delta padano: Riflessioni sul catalogo e sulla mostra ferrarese: Atti del convegno internazionale di studi Spina: due civiltà a confronto, Ferrara, Aula Magna dell'Università, 21 gennaio 1994, ed. Fernando Rebecchi. Pp. 253-273. Roma: "L’Erma" di Bretschneider, 1998.

WatKINS, Calvert. 1955. The Phonemics of Gaulish: The Dialect of Narbonensis. Language 31.1.9-19.

Whatmough, Joshua. 1921. Inscribed Fragments of Staghorns from North Italy. The Journal of Roman Studies 11.245-253.

. 1922. Rehtia, the Venetic Goddess of Haeling. Journal of the Royal Anthropological Institute 52.212-229.

1923. Inscriptions from Magrè and the Raetic Dialect. The Classical Quarterly 17.61-72.

1933. The Prae-Italic Dialects of Italy. Vol. II. Part III. The Rhaetic, Lepontic, Gallic, East Italic, Messapic and Sicel Inscriptions. Cambridge, MA: Harvard University Press. Rpt. Hildesheim: Georg Olms Verlagsbuchhandlung, 1968.

1934. The Raeti and their Language. Glotta 22.27-31.

ZAVARONI, Adolfo. 1996. I documenti etruschi. Reggio Emilia: Sherpa. 
Table 1: Concordance of Presentations of the Magrè Votives

\begin{tabular}{|l|l|l|l|l|}
\hline PID & CIRCE & Inv. No. Este Museum & $\begin{array}{l}\text { Tibiletti Bruno } \\
(\mathbf{1 9 7 8})\end{array}$ & $\begin{array}{l}\text { Morandi } \\
(\mathbf{1 9 9 9}) \mathbf{N o} .\end{array}$ \\
\hline 221 & MA-1 & & p. 237 & 38 \\
\hline 222 & MA-2 & 58811 & p. 237 & 39 \\
\hline 223 & MA-4 & & p. 237 & 45 \\
\hline 224 & MA-5 & 58813 & p. 237 & 36 \\
\hline 225 & MA-6 & 58812 & p. 237 & 35 \\
\hline 226 & MA-7 & & & \\
\hline 227 & MA-8 & 58808 & p. 237 & 34 \\
\hline 228 & MA-9 & 58810 & p. 237 & 40 \\
\hline 229 & MA-10 & 58809 & p. 237 & 37 \\
\hline 230 & MA-3 & 58811 & p. 237 & 39 \\
\hline 231 & MA-11 & 58816 & p. 237 & 41 \\
\hline 232 & MA-12 & & p. 232 & 42 \\
\hline 233 & MA-13 & 58815 & p. 234 & 43 \\
\hline 234 & MA-14 & & p. 237 & 44 \\
\hline 235 & MA-15 & & & \\
\hline 236 & MA-16 & 58819 & p. 237 & 47 \\
\hline 237 & MA-17 & & p. 237 & 46 \\
\hline 238 & MA-18 & 58814 & p. 237 & 50 \\
\hline 239 & MA-19 & 58814 & p. 237 & 49 \\
\hline 240 & MA-20 & & & \\
\hline 241 & MA-21 & & & 48 \\
\hline 242 & MA-22 & & & \\
\hline 243 & MA-23 & 58817 & & \\
\hline
\end{tabular}


Zgodnje oblike celinske keltščine (okrog 550-50 pr. Kr.) so bile razširjene v severnem alpskem pasu italijanskega polotoka od jezer Maggiore in Como na zahodu do Slovenije na vzhodu. Fragmenti keltskih napisov s tega območja so se ohranili v različnih lokalnih abecedah, na katere je vplivala prvenstveno etruščina (retščina). V teh sicer skopih besedilih lahko spoznavamo, kako se je v železni dobi pismenost razširjala z mediteranskega področja proti severu v keltsko Evropo. Zgodnje jezikovne in kulturne stike med etruščino (retščino), keltščino in venetščino pa lahko še posebej opazujemo na osnovi votivnih napisov, povezanih s čaščenjem boginje Reitije v svetišču v kraju Magrè (Schio) severno od Vicenze. Zdi se, da imamo tu pred seboj tri larijske čuvajke blaginje in plodnosti skupaj: to so Estija - Esija (Ariadna / Vesuna) - Reitija (Artemis / Atena). V članku avtor z jezikoslovnega stališča analizira nekaj magrèjskih napisov, predvsem v odnosu do keltščine, pa tudi z vidika njihovih epigrafskih značilnosti. Vezi med otoško keltščino in vzhodno keltščino, kot se odraža v italijanskem Magrèju in na slovenskem Igu, so presenetljivo in obenem enigmatično močne. Tako npr. v enem izmed magrèjskih votivnih napisov najdemo onomastično pojavitev keltske osnove boudi- ' zmaga', prisotno tudi v britanskem imenu Boudicca (sic, Tacitus, Agr. 16,1) za slavno kraljico Icenov, ki je v letih 60 - 61 pr. Kr. vodila tragično neuspešen upor proti rimskim okupatorjem. 